Article

\title{
Registers of Artefacts of Creation-From the Late Medieval Period to the 19th Century
}

\section{Chris Dent}

Intellectual Property Research Institute of Australia, 9th Floor, Melbourne Law School, University of Melbourne, Parkville, Victoria 3010, Australia; E-Mail: c.dent@unimelb.edu.au; Tel.: +61-3-8233-1134; Fax: +61-3-9348-2353

Received: 18 March 2014; in revised form: 26 May 2014 / Accepted: 26 May 2014 /

Published: 4 June 2014

\begin{abstract}
This paper offers a new perspective on the "development" of the intellectual property regimes in the United Kingdom. The system put in place under the 1875 Trade Marks Act may be seen as the last of a sequence of earlier "technologies" that sought to administer the creative endeavours of (sections of) the English population. Prior to the trade mark registration (that included examination) there was the registration of designs that did not require examination but was necessary for the protection of the right. In the eighteenth century, patent specifications were lodged with the Crown via a process that was much more involved than that was instituted for designs in the nineteenth century. Before that, books had to be enrolled with the Stationers' Company before they could be printed. And, in what may be seen as an earlier attempt at the centralised regulation of artefacts of expression, the Rolls of Arms (maintained by the King of Arms) was repository of coats of arms for English nobility. An exploration of these different technologies of regulation, in their socio-political context, will offer new insight into the antecedents, and limits, of the registration systems that are now common across the intellectual property world.
\end{abstract}

Keywords: intellectual property; registration; history; socio-legal

\section{Introduction}

The Register of Trade Marks has been the central pillar of the trade mark regime in the United Kingdom (UK) [1] since 1875 [2]. As such, the idea of a "complete" registration system has been around for almost 140 years. This form of "technology" has since spread to other areas of intellectual property (IP), for example, patents and plant breeders' rights [3]. Key features of these complete 
systems include the examination of applications by those deemed qualified to carry out the task and the collection of the examined artefacts into the register for future reference. These processes may, now, seem as the self-evidently "right" way of doing things; but, given that the trade mark register was not the first legislative scheme for the regulation of trade marks [4] and given that the earlier regulation of designs and patents followed different models [5], it appears that the register was not, at the time, obviously the best form of regulation.

This article focuses on these earlier forms of regulation as antecedents for today's IP systems. Specifically, this research is an exploration of the history of the filing of artefacts of creation [6], or details of such artefacts, with a central body. Consequently, it starts with the granting of arms in the late medieval period, proceeds to the enrolment of books with the Stationers Company in the sixteenth century and includes the lodgement of patents and their specifications, the registration of designs and, finally, the examination of trade marks [7]. A mere recitation of the legal requirements of these filings is insufficient to explain the limits, and constraints, of each form of regulation. In order to do that, there will be a discussion of the political, economic and intellectual backgrounds to each [8]. Of course, given the necessary sweep of several centuries, this work can, at best, be introductory-yet it is a gesture that allows a more nuanced understanding of the current system of regulation [9].

Implicit in this analysis of the register as an artefact is the view that it is now an integral part of the overall regulation of most categories of statutory intellectual property. It is not, therefore, just a device employed to facilitate, but not impact on, the development of IP law. In other words, the law is as it is now, in part, because of the adoption of the register [10]. The argument is that a more detailed understanding of the limits of the law requires a more complete understanding of the foundation, and limits, of this technology. This article is but one step on the way to this goal.

\section{Late Medieval Times}

There are two technologies of the regulation of forms of expression [11] that existed in the late medieval period [12]. One of these may be seen as being closer to the lineage of the current IP systems - despite the subject matter - than the other. Both need to be engaged with in order to provide the context of the regulation of creative expressions [13].

\subsection{Guilds}

Guild marks are often referred to in histories of the trade mark system on the basis that many guilds, if not all trade guilds [14], required their members to affix the guild's mark on their products. These marks certainly tied particular goods to particular guilds; and may be best understood in terms of the internal regulation of guild members [15]. Some have suggested, instead, that guild marks could be taken to be a marker of quality [16]. For this to be the case, however, buyers would need to be able to choose between different manufacturers of the same product — and given the more localised markets of the time [17], it's not clear that this would always be the case.

What is key here, instead, is the fact that the guilds were responsible for their own marks. There was no centralised register of guild marks, nor was there an office of the Crown that was charged with monitoring new marks or the use of existing ones. There were a (small) number of Acts that did compel the use of marks - such as the fifteenth century statute that related to arrow-heads [18] and the 
sixteenth century one covering pewter manufacturers [19] — but they did not require these marks to be recorded and any monitoring was done via the guilds [20]. The guilds, therefore, regulated themselves and regulated the use of their marks; and, as McKenna has pointed out, it is "not clear how often mark owners sought enforcement of their marks" ([16], p. 1850). As a result, there is not much in common between such marks and the registration system in place in the twenty-first century. Unsurprisingly, Schechter also considered that these guild marks were "very remote in their essential significance from the modern concept of a trade mark" ([14], p. 38; [21]).

\subsection{Kings of Arms}

The second late medieval system to be considered here relates to (coats of) arms [22]. This article is not the first to consider the heraldic system as being relevant to the history of trademarks [23-25]; it is, however, the first to link the processing of claims for new arms with the broader story about the development of IP regulation [26]. It is argued that, commencing in the early fifteenth century, the "lodging" of prospective arms with the King of Arms is an early form of centralised record keeping [27]. Further, the arms themselves may be seen as a form of self — or at least familial—expression.

In terms of who could bear arms, the 1486 Book of St. Albans

mentions four grounds on which a man may claim title to arms: because he inherited them; or on account of the tenure of a particular fee or office; or on the ground that he has been granted them by some lord or prince; or, finally, because he captured them from an enemy in battle ([28], pp. 129-30; [29]).

This description suggests the controlled manner in which the right to use arms could be transferred from one person to another. Of course, not all members of the population could bear arms, but by 1250, the use of arms was "prevalent among knights" ([30], p. 25; [31,32]). By the time of the War of the Roses, the bearing of arms had "been for several centuries the indispensable indication of acquired or hereditary honour" with the arms providing "unequivocal information of the bearer, not only with respect to his paternal descent, but to his lineal agnation" ([22], p. 128). The bearing of arms, then, was linked to the nobility and the right of particular individuals to demonstrate that they are nobles [33,34].

In terms of how arms could be granted, according to Ashman, the "earliest definite instance of the exercise of the authority and prerogative of the Crown in matters armorial" was in about 1394 ([29], p. 59; [35]); though Wagner asserts that "grants of arms by the English Crown are at all periods very rare" ([36], p. 67). In another publication, Wagner notes that the "first explicit reference... in a King of Arms' patent to authority to grant delegated by the King is in a patent of 1467” ([30], p. 39; [37]). That is not to say that any authority exercised was complete: "as late as the fifteenth century it is clear that many assumed arms of their own will" ([28], p. 130). That said, Richard III, in 1483, incorporated the heralds into the College of Arms; the "chief" power of that organisation was the "granting [of] armorial ensigns" ([22], p. 138).

There are few readily available descriptions of all the processes adopted by the College and the Kings of Arms [38]. Wagner details some practices - such as the different Kings of Arms not being able to grant arms to people in the marches, or "jurisdictions", of the other Kings, and the need for licences for particular practices ([30], p. 67). It is known, however, that a key function of the King of 
Arms was the "visitation". The purposes of these visitations, at least from the early sixteenth century, were to "correct arms unlawfully borne and to enter those borne lawfully with the descent of those who bore them" ([36], p. 2). According to Dallaway, visitations were "regularly made every twenty-five or thirty years" ([22], pp. 165-66); and, importantly, they were carried out under the authority of a letter patent issued by the Crown ([36], p. 2). The information gathered as a result of these visitations meant that the heralds kept the "records of armorial bearings" ([39], p. 44) and "heraldry had become a science [for, inter alia] recording genealogical information" ([28], p. 134). It may be noted that this data was subject to searches by the heralds ([30], p. 132), but the authorities are less clear on whether the records were searched before new arms were granted.

The final piece of heraldic regulation to be discussed here is the Court of Chivalry [40]. The earliest evidence of its rulings on disputes as "to armorial bearings" was from the second half of the fourteenth century - though there were only a handful of them ([41], p. 16; [42]). Though the Court did not have a significant role in the operation of the system of arms, it still represented a centralised institution, under the auspices of the Crown, that functioned, in part, to maintain the integrity of that system.

\subsection{Context}

While the details of these systems are now sketchy-given the half millennium that has passed since their heydays - there is enough to connect these forms of regulation with the broader societal institutions. While it may be strictly incorrect to suggest that the forms of governance of the time were feudal [43], the technologies of "power" were different then to what exists now and, further, were (less) different to what existed in the early modern period. England did have monarchs; however, the geography of the country meant that a degree of power remained in the hands of the local lords [44].

The most obvious aspect of the time, then, was the relative importance of the nobility. Parliament existed, but its role was more restricted than it is today. Admittedly, the power of the nobles had decreased, from the height of the feudal era, by the fourteenth century [45], but that did not mean that they were without authority. So, it was the nobles who sought, and were granted, arms as a marker of their place in society ([28], p. 164). It was also in this period, the thirteenth and fourteenth centuries, that the statutes relating to scandalum magnatum were passed. Under these Acts, it was a "criminal offence to slander the "great men of the realm"” ([46], p. 75). These "great men" were the Dukes, Earls and Barons of England - men who competed with the King for control of the land and the ones entitled to bear arms. Importantly, however, the regulation of arms became centralized (as were the courts that adjudicated the slanders) - and centralisation, in that era, meant a shift in control from the nobility to the Crown, a process that continued into the early modern period.

In terms of the operation of the market [47], it was the guilds that had significant power in the late medieval period. Further, it was the nobles, the land-owners, who had control over the production of primary produce ([48], p. 258; [49]). It has been suggested that there was the flow of money between the towns and countryside - between nobles and the bourgeoisie - that helped the maintenance, and development, of both areas of endeavor ([50], chap. 3; [51]). The Crown, on the other hand, had a more limited role; to a large extent, it was only about regulating coinage and the weights and measures used in the markets [52]. In this environment, it is not surprising that the forms of regulation of 
symbols and signs focused on the attributes of the guilds and the nobles, rather than on any other population of the time.

That said, Strayer has noted that by the fourteenth century, "some of the essential elements of the modern state [had] begun to appear" ([53], p. 34). One of the key elements was the development of the Chancery and its clerks. Their work - the recording of charters, close and patent rolls - provided a "register" of those which had been granted by the Crown ([54], p. 69). Here it is worth noting the distinction that may be drawn between information that is retained for the purposes of the institution that created it and the maintenance of a record by a body other than its creator. As stated above, the guild marks are less relevant to this history because information about the marks was not centrally stored (though their relevance to the history of the regulation of the market remains). Similarly, the Church, as with the Chancery, was a significant repository of medieval knowledge but it tended to keep information that it, itself, generated. In sum, the point here is not to argue that either arms, or the guild marks, were a necessary precursor to the current trade mark system — only that the operation of the Kings of Arms, and the heralds, was an early example of a centralised and regulated system of information collection, assessment and enforcement (and, therefore, with similarities to the trade mark registers of today).

\section{Early Modern Period-Stationers' Copyright}

In the early modern period two forms of IP rose to prominence. One was the patent; though, patents, at that time, were not solely for inventions as we now know them to be. The system for gaining a patent was not about maintaining a central register of ingenuity but, instead, centred on the grant of the royal prerogative as an act of administration [55]. What is more important here is the process by which stationer's copyright was gained; that is, how books became to be regulated through the operation of the Stationers' Company. It should be noted that the chronological order of the discussion here (i.e., the detail of the early modern system coming after the discussion of the medieval period and before the discussion of the nineteenth century registers) is not intended to be an implicit argument for a conscious development (in a teleological sense) of the register as a technology. The question of the (lack of) deliberate progress towards today's registration system is discussed below.

\subsection{Features}

It did not take long, after the introduction of the printing press to England, for the industry to be regulated. This is not surprising given that the Tudor "governments directed their regulatory efforts to the maintenance of social order, public peace, national security and the achievement of economic prosperity" ([56], p. 226). For Patterson, there were three aspects of this control in the sixteenth and seventeenth centuries - the "stationers' copyright, the printing patent and government press control" ([57], p. 4).

The printing privileges, or patents, first appeared, in England, in 1518 ([58], p. 11; [59]). The stationer's copyright arose from the charter, granted in 1557, that formed the Company of Stationers of London. Both of these allowed the recipient to publish books [60]. This freedom was not absolute. There was the strong suggestion that the authorisation of printing was to further the interests of the State [61]. Deazley, for example, notes that the Stationers' Company charter provided the Crown with 
a "method of controlling the printing of (what they considered to be) seditious and heretical material" ([62], p. 2, note 4). It may be highlighted, too, that some of patents granted were for specified books ([63], p. 4; [64]) or classes of books [65,66]; this suggests a significant level of "fine-grained" control that exemplifies the claims about the Tudor mode of governance. Licensing, therefore, was antecedent to the printing and it was only those books that were condoned that were allowed to be published (though this is not to claim that only authorised books saw the light of day) [67].

It is, of course, the entering of books into the Stationers' Company register-or more fully, the Register Book of Copies - that is of most importance here [68,69]. As with the registering of arms with the College of Arms, there is not a huge amount of detail available about the procedural aspects of the "registration" of books in the early modern period. According to Patterson, to enter a book required that a manuscript would be submitted to the Company's wardens after it had been "licensed by the official authorities" ([57], p. 52). Ransom also highlights that a "registration fee" was also payable ([59], p. 39, quoting Arber). The information recorded on entry seems to have changed over the life of the company - "gradually... the form of entry evolved away from one that emphasised the action whereby the company granted exclusive rights toward one that emphasised the member's proprietorship" ([58], p. 12; [70]). Regardless of any such change, the register remained a list of books that could be (lawfully) printed with some information kept about those books.

There is a degree of debate about the importance of the entrance of books into the Company's register. According to Birrell [71], "no person should print any book or pamphlet until the same had been first lawfully licensed and entered upon the register" ([65], p. 60; see also [67], chap. 7; [72]). On the other hand, the "mere existence of a previous entry would not necessarily be conclusive" should a dispute arise ([67], p. 223). Patterson, further, highlights a debate as to the necessity of entry for the purposes of gaining copyright ([57], p. 56). It may also be noted that it was possible to enter a book that was yet to be produced: "by entering a generalised title, [members] could prevent the subsequent entrance of competing books in a given subject" ([67], p. 218). That said, there may be doubt as to the extent that the Register was searched in order to see "whether a proposed entry would infringe one previously made" ([63], p. 5). Such a task would have been difficult given the fact that "its many thousands of entries remained both unindexed and without cross-references" ([67], p. 217).

It should not be forgotten that the Register was an instrument of the Company-a private entity, an authorised body but not an office of the state. As Johns puts it, the "authority of the register originated in Company convention, and not directly in the law of the land" ([67], p. 219). It is, nonetheless, clear that the Company was given the power to enforce their right to print books. It could, for example, "search out, seize and destroy books printed in contravention of [their] monopoly" ([59], p. 29; [73]). It is also clear that the Company had an internal procedure, a Court [74], for the administration of the rights that arose as a result of the Company's activities ([59], p. 41; [75]). Given the central importance of the books entered into the Register, the "court developed an elaborate practical taxonomy of similarities and differences between texts" in order to resolve disputes ([67], p. 226; [76]).

Finally, there is also some uncertainty as to the discretion that the Company had with respect to the registration of books [77]. Section 3 of the Statute of Anne allowed for the gaining of "copyright" (though the Act did not use the term "copyright") over a book where the "clerk of the said company of stationers for the time being, shall refuse or neglect to register, or make such entry or entries" [78]. That legislative action was necessary suggests that the monopoly over entry to the register was causing 
a significant problem. There is not much evidence, now, as to the extent of the problem [79]; however, it is possible that given the Company's private purpose, its decisions were aimed at the benefit of its members. Therefore, there may have been (many) instances where the entry of a book on its register was not in the Company's members' interests.

\subsection{Context}

The Stationers' Company is indicative of the politico-economic structures of the early modern period in that the company was incorporated under a royal charter. It was not a guild, though it did start out as a guild ([57], p. 29); and it was not a loose collection of individuals bound together only by their word (either spoken or written). The Company, as a company, represents a shift from the medieval forms of governance - specifically, by the end of the sixteenth century, the "entire system of guild regulation" was in "decay" ([80], p. 24) and the companies were taking their place. Again, the fact that the Crown granted these new entities charters indicates the growing power of the monarch [81], and her or his inner circle [82], with respect to the more regional powers of the nobles and guilds [83].

That the Company used a register may be seen as an example of a shift in the attitude of knowledge as knowledge $[84,85]$. Given the religious divisions of the sixteenth century, it is not surprising that the Crown worked to limit the spread of what it saw as "heretical" material [86]. This desire, and ability, to control knowledge is, arguably, another shift from the medieval period in that knowledge, and the perpetuation of that knowledge, was no longer the province of the Church $[87,88]$. It was only during, and after, the Reformation that the understanding, and approach, to knowledge shifted significantly [89]. In other words, it was in the early modern period that the "furtherance of scientific and scholarly knowledge" ([90], p. 26) - the objectives of a new, more secular, university system - took hold. Knowledge, qua knowledge, was becoming an object of study in its own right [91].

It was also in the late sixteenth century that the body of knowledge that came to be known as mercantilism became established [92]. These writings are important because they represent an early example of the application of analysis to policy and because of the relationship between the writers and the Crown [93]. It should be noted that the mercantilists were merchant traders [94,95], first and foremost, but they published books to further their interests (and what they saw to be the interests of the nation). It was, though, their positions with the trading corporations that gave them the ear of the monarch and Parliamentarians [96]. Further, it was clear that, at least with respect to Elizabethan policies, "it was an indisputable part of the Crown's prerogative that it could regulate external trade in what it deemed to be the public interest" ([97], p. 117); - international trade, then, was under the authority of the Crown and yet outside its specific expertise. The mercantilists, or those with the knowledge, therefore, adopted, and published, positions based on their knowledge and experience that also furthered the interests of the Crown as a centralised authority [98]. The centralising function of international trade $[99,100]$, and the mercantilist justifications for it, again buttresses the overall Tudor strategy.

The regulation of the publishing of books is linked to the "economic" and political structures of the early modern period. Of course, books themselves had a wider relevance. Greenfeld, for example, considers that the literature of the time, that is the printed books, as being a key aspect of the rise of the nationalist spirit in England ([101], p. 46; [102]); and Ransom's assessment that the regulation of 
books in the early modern books is the "clearest example of... centralization" ([59], p. 24) reinforces the overall arc of governance of the time. The use of a register as a mode of regulation reflects a changed attitude to knowledge - it can be ordered and organised (though, as suggested above, the Stationers' Register, with its lack of indexing and cross-referencing, was not was organised as a register would be today). The register, therefore, is differentiable from the collection of records of the late medieval period. In short, the register was an administrative technology that had significance for the conduct of the industry — with that industry playing a regulatory role for the Crown.

\section{Eighteenth Century_Patent Specification}

One of the key shifts, post the early modern period, was the move from a "private" (albeit authorised) body to a State one - though, of course, the Statute of Anne still had the Stationers' Company maintain that register [103]. That is, the collection of "data" for patents was carried out by a centralised, government entity [104]. There were, unsurprisingly, other changes in the regulation of IP in the eighteenth century - including the passing of a number of Acts relating to copyright and designs [105] — but, as they did not involve registration, they will not be considered here.

\subsection{Features}

It was in the eighteenth century that the administrative practices around patents for invention developed. Of course, the technology of regulation, the patent itself, was already centuries old by that time [106,107]. What changed in the eighteenth century was the introduction of the patent specification [108]. Up until the major reforms of the nineteenth century [109], there was a long and convoluted process for applying for a patent. Descriptions of this "enormously cumbersome and prohibitively costly" process ([110], p. 19), are readily available and, therefore, will not be reproduced here [111]. It is sufficient to state two things about it. First, it was very much a grant of the Crownthere was a petition to the Crown, visits to the Home Secretary, the Attorney- or Solicitor-General, a signet bill from the Lord Keeper of the Privy Seal and the signature of the Crown. Second, the "patent system was one of simple registration" ([112], p. 41); meaning that, to a large extent, as long as the relevant administrative procedures were completed properly, the applicant had a patent.

Ever since the sixteenth century, some patent applicants provided a description of the invention as part of the "hurdle-jumping" [113]; for Davies, the early patentees "chose" to do so in order to "advance their claims" despite it being "unnecessary for patentees to submit any descriptions in writing" ([114], p. 263; [115]). In 1734, however, for one commentator, the provision of a specification by the prospective patentee became a "standard requirement" ([116], p. 365). For another, citing analysis of Woodcroft's Index of patents, 73\% of applications, in the decade post 1733, included a specification ([117], p. 32). And for a third commentator, it was not until the decision of Liardet $v$ Johnson $[118,119]$ that the "specification would be officially enshrined by the law courts as a requirement for a valid patent" ([120], p. 1287). There is no need to spend time aligning the three perspectives, it is sufficient to note that the specification took on an increasing level of significance in the course of the eighteenth century [121].

In terms of what was contained in the specification, one anecdote, relating to one of James Watt's patents, contained the assertion that 
I send you, enclosed, three yards of the specification, and have about one yard more to send... You may, perhaps, think the specification long, but I can make it no shorter, to be full and complete, as the Law requires ([122], p. 126; [123]).

A question, then, becomes - "what is the difference between the descriptions that were part of many seventeenth century applications and the specifications of the late eighteenth century?" In part, it was about the level of detail enclosed - as suggested by Bottomley's assertion that a specification was not necessary in the middle of the eighteenth century where the "description in the petition was particularly thorough" ([117], p. 32). In part, it is a matter of procedure-with the specification a "document separate and distinct from the patent itself [and filed] some specified time after the patent had been sealed" ([121], p. 785).

It may be noted that there was not "substantive" examination of the level of invention inherent in what was described in the specification [124]. That is not to say that all applications were approvedjust that the inquiries were much more limited than examination in the twenty-first century. Bracha states that

unless a patent was challenged, only one out of ten of the bureaucratic stages involved was more than a mere formality [with] the only substantive review [being] the report of the law officers, either the Attorney-General or the Solicitor-General, regarding the Statute of Monopolies requirements ([125], p. 202).

Further, if challenged in the courts [126-128], the only issue with respect to novelty was whether the invention had been "worked within England within recent memory" ([129], p. 848; [130]); it was, therefore, not a question of whether it was new to the world or even new to the country [131].

It is not clear, now, why the requirement of filing a specification was introduced-as has been pointed out, "no direct evidence appears to exist about the origin of the practice" ([104], p. 159); or, expressed differently, it is not clear what the benefit of the requirement was. There are five categories of potential beneficiaries: the patentee $[132,133]$, the patentee's competitors, the government, the public at large or the "register"- the compilation of knowledge that the combined specifications represented. That it was not in the patentees' interest is suggested by the fact that an additional fee was payable on the specification's filing ([108], p. 35) and that it gave more information upon which a challenge may be made to the grant [134]. The government's interests are clear-in terms of its interests in restricting monopolies, and as MacLeod suggest differentiating "between superficially similar inventions" and assisting in the "shift [of] responsibility from the law officers to the courts" ([112], p. 51; [135]. Despite the debate, what is important, for the purposes of this paper, is that, even prior to the nineteenth century reforms, complete specifications were open to public inspection on payment of a fee [136]. That said, given the lack of indexing, it is not clear how accessible, in practice, the information was ([108], p. 37).

\subsection{Context}

There is a single key aspect of the societal context that had changed from the early modern period to the middle of the eighteenth century. That was the English Enlightenment. A number of other features of the nation were "by the early eighteenth century" conducive to an expansion in the use of 
the patent system including a "market-oriented economy, a good standard of living [and] a significant mercantile class" [137,138]; however, these characteristics do not seem to, directly, lead to the need for the specification to be part of the patent application process. In other words, on one hand, Getz has argued that the shifts in the "economic structure of England", from 1600-1750, were of "decisive significance" to changes in who used the patent system - namely, the "emergence on one hand of the industrial capitalist and on the other of the dependent employee" ([139], pp. 77-78; [140]); on the other, the "archaic and costly procedures" that governed the patent application suggests that, while the economy was changing, the administrative aspects of government was not ([110], p. 21).

With respect to the Enlightenment, it was in the period 1660 to 1760 that "innovation, traditionally an effective term of abuse, became a word of praise" ([141], p. 3). An "idea", a "new idea", as a separate, knowable, construct for analysis is a product of that time [142]. The law of patents also changed as a result of this new perspective. It is arguable that it was as late as 1799 that there were doubts in the minds of judges as to the patentability of what we now consider to be discoveries [143]. More generally, it is clear that the issue of whether or not principles were patentable was raised as a concern in the decisions of the courts only after the Enlightenment [144]. It is no surprise, therefore, given this interest in new knowledge that the use of the specification grew over the course of the century of Enlightenment. That is, the added level of detail of the specification, when compared to the earlier descriptions, goes to the value that knowledge itself was seen to have. By the middle of the eighteenth century, the Crown had come to "recognise that working the invention was no longer the consideration for the grant, but that instead wider dissemination of new skills to the public in general should be the desideratum" ([121], p. 792; [145]). To be clear, in that century, it was not the "person skilled in the art" (PSA) who was the target of the information in the patent - the law was yet to refine that concept - it was a more vague idea that some individuals in the community would benefit from the detail provided rather than the more precise articulation of the PSA that is extant today.

Reference may be made, here, to the case law that developed around the purpose/s of the information contained in the specification. Two of the earliest references were in the 1785 Arkwright decisions - both contained in addresses to juries. For Lord Loughborough, the specification should be

so intelligible that those who are conversant in the subject are capable of understanding it and perpetuating the invention when the term of the patent is expired. The clearness of the specification must be according to the subject matter of it; it is addressed to persons in the profession having skill in the subject, not men of ignorance ([146], p. 50).

Further, for Buller J., for "a man to entitle himself to the benefit of a patent for a monopoly, must disclose his secret, and specify his invention in such a way, that others may be taught by it to do the thing for which the patent is granted" ([134], p. 78). The report of Liardet $v$ Johnson holds that the issue is "whether the specification is sufficient to enable others to make it up" ([147], p. 37). In Boulton v Bull, there are references to "the public", "artists", "a mechanic" and "workmen" as the people who could make use of the information [148]. Finally, in Hornblower v Bolton, there were, again, references to "artists" and "mechanics" taking advantage of the specifications [143]. In short, there were a range of categories of individuals who were understood to be the proper addressees of the specifications - unlike the technical description of the PSA today [149]. 
It is arguable, too, that the Enlightenment coincided with the decline in Crown control over the dissemination of books [150]. This suggests a shift away from centralised regulation over knowledge generally. This is supported by Walterscheid's observation that "perhaps the most remarkable aspect of English patent practice in the eighteenth century was... [that] with only limited exceptions, there was no attempt to use patent practice as an instrument of government policy" ([151], p. 88). Further, the greater role given to the (centralised) courts in the patent system in the eighteenth century, coupled with the provision of greater information that would enable competitors to challenge patent grants, also represents a shift away from a state-regulated system towards one guided by individual self-interest $[152,153]$. This spreading of the responsibility of accountability matches the "more rapid and widespread diffusion of skills [that] could clearly be more efficiently achieved by publishing full details of the invention than by requiring the patentee to employ a specified number of Englishmen in working it" ([139], p. 81). Further, the growing focus on the knowledge possessed by workers (in terms of the teachings contained in the specifications), as opposed to the early modern concerns of simple employment, may be seen as a (small) step towards the "knowledge economy" that exists in the twenty-first century.

\section{Nineteenth Century}

The nineteenth century saw a significant expansion of the operation of the IP regimes. These changes culminated in two major multilateral agreements [154] and significant domestic statutes [155]. That said, the foundations of the systems regulating the expressions remained the same in that they still involved a centralised state body recording information, though, in the nineteenth century the practices were becoming more administrative. Two areas of IP will be considered here: designs and trade marks [156].

\subsection{Registration of Designs}

It was in 1839 that an Act was passed that made registration a condition for the protection of a species of what is now understood to be IP-An Act to Secure to Proprietors of Designs for Articles of Manufacture the Copyright of Such Designs for a Limited Time (the 1839 Designs Registration Act) [157] — as Sherman and Bently have noted, this was the "first modern administrative system for the issuance of intellectual property" ([7], p. 68). In order for a "proprietor" to gain the benefits of the Act, the design had to be registered with the "Registrar of Designs for Articles of Manufacture" (s. 1) [158]. A number of aspects of the system may be highlighted - first, the "author of every such new and original design shall be considered the proprietor" (s. 1) [159]; second, "three copies or drawings" of the design needed to be filed (there was, however, no provision for the examination of these copies to indicate originality [160]; and, third, a "classified index" of registered designs needed to be maintained by the Registrar (though the Act is silent as to who may inspect the register or search the index) (s. 6). Importantly, the Registrar was an organ of the state - one that was expressly created for the purpose of dealing with design registrations [161].

The 1839 Designs Registration Act, however, was not intended to "revolutionise" the protection of designs. The Act, for example, was not the only way a proprietor could protect her or his innovation. As highlighted above, there had been statutory protection for some designs from the middle of the 
eighteenth century - the 1839 Act did not repeal all the previous pieces of designs legislation. Further, there was another designs statute passed that year-An Act for Extending the Copyright of Designs for Calico Printers to Designs [162]. There was no overlap between the two Acts because the Designs Registration Act did not apply to designs to be featured on lace, linens, cottons, calicoes and muslins (as well as other materials covered by the Schedule to the Act) (s. 1) [163]. The introduction of the register, therefore, did not represent a "totalising" technology - it was only another technique that some innovators could choose to use, if they saw it in their interests to do so.

It was only in 1842, with the passing of the Act to Consolidate and Amend the Laws relating to the Copyright of Designs for Ornamenting Articles of Manufacture (the 1842 Designs Act) [164], that the various protection systems for designs were consolidated. In addition to the features of the register under the 1839 Act, the later statute allowed for the cancellation or amendment of registrations (s. 10) and provided the opportunity for "every person ... to inspect any design" on payment of a fee (s. 17). The right of inspection, however, only applied to expired designs. Finally, it is worth noting that "piracy" of registered designs was defined in terms of either unauthorised use, or the "fraudulent imitation", of registered designs (s. 7).

Reference need also be made to the reasons for the institution of the formal registration system. It has been suggested that the registration system was intended to limit the need for proprietors to use the "expensive" process of copyright infringement litigation to protect their designs ([165], p. 79). That said, according to Cornish, "nothing was done to provide a more efficacious tribunal for enjoining infringers than the cumbersome Court of Chancery" ([156], p. 223) — but it should not be glossed over that it was the Court of Chancery (a major Crown institution) that did hear the cases. Bently offers two more nineteenth century reasons for registration - that the "system could publicise good designs" and that it was part of the "environment of ever expanding government involvement, regulation and control" ([160], pp. 33-34). For some, the former of those two reasons was a basis for complaint-the capacity for the register "to provide inspiration for other designers"-was a key objection to registration for the calico printers ([7], p. 69). Their perspective, however, put them at odds with what may be seen as an overall trend towards the centralisation, and diffusion through society, of information and knowledge.

\subsection{Examination of Trade Marks}

As highlighted in the introduction, it was in 1875 that a registration system was introduced into the UK trade mark system - though, more properly, it may be described as an examination system [166]. Key aspects of the new regime included [167]:

- Registration as a prerequisite for bringing infringement proceedings under the Act (s. 1) [168];

- The requirement that marks be registered with respect to particular classes of goods (s. 2);

- The capacity to rectify the register with respect to the ownership of trade marks (s. 5);

- The implied examination of applications to ensure that they are not identical to trade marks that are already on the register, or be "so nearly resembling" a registered mark "as to be calculated to deceive" (s. 6); 
- The unlawfulness of "scandalous designs" (s. 6);

- The advertisement of trade marks that had been applied for (s. 7);

- The capacity to remove marks from the register (s. 7);

- The possibility of inspection of the register (s. 7) [169]; and

- The certificate of registration being evidence of registration (s. 8) [170].

In short, the system is looking more complete, and arguably more "modern", than the design registration system of 1839 - to a large extent, simply as a result of the need for applications to be judged against those already on the register and to ensure that they are not scandalous. Conversely, the language of the Trade Marks Registration Act, with respect to actions for infringement of the right (in that an action only be instituted to protect registered trademarks), mirrored that of the 1839 Designs Registration Act. In practice and in time, however, the "courts clarified that marks that were not registered could [still] be protected if they had been used" ([10], p. 35; [171]). This is not surprising given the assessment that the Act "did not purport to establish a self-contained or exhaustive scheme" ([172], p. 28).

It appears that the over-arching justification for the passage of the Act was the rate of fraudulent imitation of marks in the marketplace [173]. The value of the register, from this perspective, is the record of specific marks and their registered owners. That is, the certificate of registration would prove that the mark was in existence and was owned by a specific individual (with the use of the mark by other people, prima facie, an infringement) [174].

It is not clear, however, why such a record requires the allocation of classes of goods $[175,176]$. There is, of course, a small amount of case law, preceding the Act, which suggested that infringement could only be proved if the offending mark was on the same type of good as manufactured by the plaintiff (of course, as there were no registered marks, these decisions may also be seen as "passing off" cases). There appears to be three pre-1875 cases that discuss this [177]—Ainsworth $v$ Walmsley ([178], pp. 524-25); Hall v Barrows ([179], pp. 158-59); and Leather Cloth Co. v American Leather Cloth Co ([180], p. 141). Each such statement, however, may be best seen as obiter dicta-as the alleged infringements related to the same category of goods as produced by the plaintiffs [181] and each were made in the context of the then disputed issue of whether trade marks were "property". Further, it is, at least, arguable, that the adoption of complete classification scheme (as in the creation of multiple, specific classes [182]) is more than was necessary, given the fact that to have the applicants list the goods upon which they intended to use the mark would have been sufficient to fulfil any common law requirement.

That said, there were two specific effects of the introduction of the classification system. The first of these was that, necessarily, the scope of the monopoly that any proprietor would gain as a result of registration would be narrowed - a key concern of some of those involved in the reforms of the trade mark system - in other words, a trade mark owner who owned the monopoly to the use of the mark with respect to specific categories of goods had a narrower right than if the mark could have been used on any category of good [183]. Second, it is also possible that the classification was used as, even if it was not intended to be used as, a search tool for those who assessed the applications. It would have been easier for that person to confine the search of registered marks to those categories listed on the 
application than to search the entire register. This practical effect of the classification system would fit with the trend towards bureaucracy evident at the time, however, there is little evidence of this, as an intentional outcome, in the literature.

\subsection{Context}

The nineteenth century is often seen as one of great reform - particularly with respect to the law. Three areas of thought that may be seen to have contributed to the introduction of the registers into IP law will be considered here. The first is the doctrine of utilitarianism; the second relates to the rise of the idea of "law as science"; and the final area is that of economics, or as it was known of then, political economy.

This piece is not the first to link IP reforms to the philosophy of utilitarianism [184]. Important here, though, are the links between utilitarians and the general push for law reform for much of the nineteenth century. Bentham, a key utilitarian,

was not a revolutionary; he believed in action through Parliament. He attacked abuses, such as the confusion of the law... He did not threaten private property, but tried merely to prevent the "sinister interests" of any one class encroaching upon the general convenience. He believed that security of possession was more important than equality of distribution ([185], p. 36).

At one level, this is a simplistic reading of Bentham's corpus [186-190]; however, it is sufficient to highlight a number of the utilitarian beliefs that are of relevance to the shifts in the technologies of registration in the nineteenth century.

First, and obviously, there is the push for legislative reform - a purpose of which was to simplify the law and make it more accessible. Second, there was the "democratisation" of the law. Utilitarianism, it almost goes without saying, rests on three assumptions: (1) that there are individuals that can suffer pleasure or pain; (2) that in society there are different people who will be suffering different amounts of pleasure and pain; and (3) that the numbers of people may be known (at least in theory) [191]. Tying these two aspects of the philosophy together-for Bentham, "each individual always pursues what he believes to be his own happiness. The business of the legislator, therefore, is to produce harmony between public and private interests" ([142], p. 741; [192]). In practice, a register facilitates the equal treatment of applicants [193]. Anyone, for example, may create a new trade mark; there is no need for them to have had to have owned a business (in order to establish goodwill) before they could gain access to a device that had the potential to improve commercial success. And, of course, a register provided the "security of possession" that may be seen as the third utilitarian belief referred to above [194].

Two other nineteenth century examples of legislative, and societal, reforms may be referred to demonstrate the impact of the utilitarians and the changing attitudes to knowledge and its recording [195]. The first is the rise of the public library and the second relates to the organisation of the administration of state. With respect to the former, a key shift was the passing of the Public Libraries Act 1850 [196,197]. This Act facilitated the spread of libraries across the country-with each of them being accessible "free of all charge" (s. 7). Unsurprisingly, utilitarians were key supporters of the 
public education [198] — to the extent that Seville suggests that the utilitarians" "great belief in the power of education" was a force acting against the passage of the 1842 Copyright Act ([199], p. 63). It is also worth noting, though, that technology_including the development of steam-driven presseshad a significant role in increasing the number of books available for circulation ([200], p. 122). In terms of the organisation of the libraries, the systems that are in wide use today (such as the Dewey decimal system) were not developed until the late nineteenth century ([201], pp. 204-05; [202]) again, an indicator of the conceptual advance that the trade mark classification system was [203].

In terms of the administration of the state, the Public Records Office (PRO) was established in 1838 [204]. This had been prompted, in part, by the fact that the "country's records were scattered over a large number of unsafe and unsuitable buildings, under...a multitude of imperfectly responsible keepers" ([205], p. 277). The Master of the Rolls was given the power to "make rules for the management" of the Office, including with respect to "such person as ought to be admitted to the use of the records... and to fix the amount of fees (if any)" for access to the records (s. 9). Initially, the Office was responsible for Court records only, but in 1852, its responsibility was extended to the records of government departments - so that the Office became the "strong box of the Empire" ([206], p. 227). As with the public library, the creation of the PRO was in keeping with the utilitarian, if not the positivist, ideas of the time [207].

Perhaps more important is the shifts in the understanding of the law that took place in the nineteenth century. The legal positivist school grew as a reaction to the natural law jurisprudence [208-210]. Key thinkers included Jeremy Bentham, John Austin, Henry Maine and Stephen Leake [211]. Bentham, of course, provides a link between utilitarian ideas and the legal positivists [212,213]. Further, Austin adopted a classification system in order to better understand the operation of the law [214], Maine posited a "new science" of law ([215], p. 49) and Leake argued for a Linnean "systematic arrangement of the law" ([216], p. 8). Each of these imply, or require, a regime of ordering of legal "artefacts" that will provide, as a result, a deeper knowledge of the law. Admittedly, the extent to which these ideas directly impacted on the institution of registers in nineteenth century IP regimes is not clear. It seems unlikely, however, that the number, and profile, of positivists would have had no impact on the reforms in this area.

Finally, the eighteenth century, of course, also saw the beginnings of the "classical" theory of economics as evidenced in Adam Smith's Wealth of Nations - one that was only possible after the Enlightenment. However, this development may have played a greater role in the reform movements of the nineteenth century rather than in the changes around the use of the patent specification. Again, other commentators have highlighted the use of the language of political economy in the latter century [217]; it is, nonetheless, worth referring to the shifting theories of value in their work that, as will be discussed later, has relevance to the changing regulation of IP.

John Locke is known for his elucidation of a labour theory of value [218]; and the theory is still used to support IP rights (see, for example, [219,220]). Ricardo, and other classical economists, accepted the importance of labour [221] but developed the link between exchange and labour ([222], p. 277; [223]). This emphasis on exchange allowed a more abstract understanding of the market and its regulation [224]. This privileging of exchange also may be seen to lead to a support for competition; however, the classical economists still required a level of morality to exist-John Stuart Mill, for example, argued that "in the economy of society, if there be any who suffer physical privation or moral 
degradation... [then this] is pro tanto a failure of the social arrangements" ([225], p. 246; [226]). Of course, a form of morality was still at the heart of the IP systems of the time-transgression under the nineteenth-century statutory regimes was based on the concept of "fraud" [227].

Finally, there are "cross-overs" between matters economic and the work of the legal positivists. Maine, for example, "provided an authoritative legal rationale and the guiding academic spirit of the middle-class entrepreneurial attitude" ([228], p. xvii; [229]). More specifically, the importance of exchange to the political economists matches Maine's focus on contracts [230,231]. Again, this is not proof of any causation between the intellectual endeavours of the day and the creation of registration and examination systems in IP law; however, it does support the suggestion that the Trade Marks Registration Act did not emerge from a vacuum.

\section{Register as "Technology"}

This final substantive Part of the article draws together the sequence of "registers", and their contexts, described above. Three aspects of the "progression" are to be engaged with. First, the role systematic data collection has in defining the entries will be considered. Second, the operation of the registers as repositories of information will be addressed. Finally, a brief discussion of the perception of a teleological progression is required.

\subsection{Delimiting the Entries}

The inclusion of a piece of information in a central document is, at one level, a simple administrative procedure. At a deeper level, the process is an exercise of power. Two aspects of this need to be raised here: first, the defining, and second the controlling, of the features of the technology.

\subsubsection{Defining}

It is tempting to claim that, once an entry is made into a register, then it is fixed - that is, its scope becomes definite and limited [232]. Of the processes described above, that seems to be the case for guild marks and arms in the medieval period. These two categories of expression comprised of (relatively) simple designs that either were readily reproducible (in the case of guild marks) or readily described (in the case of arms) [233]. The protection afforded by the register, in these cases, was against misidentification - in effect, was the appropriate entity behind the use of the symbol in a given instance (did a member of the guild, in fact, produce the artefact with the guild mark on it or was the right knight bearing a given set of arms)? That said, arms were not filed with the King of Arms to protect the owner from "forgeries", and, as noted above, there was no central register of guild marks.

The later creations, on the other hand, were registered in order for those creations to be protectedthey were "commercial" artefacts in a way that arms, at least, were not [234]. The detail recorded on the register, therefore, had a role in that protection. For books entered with the Stationers' Company, the entry could be as limited as the title and the owner; it was, though, the complete book that was protected. The concern, at the time, appears to have been "piracy" of the complete book, rather than an incomplete copying [235]. Under the Designs Registration Act, either a complete, or a partial, copy of 
a registered design would be considered piracy (s. 3) [236]. For these categories, the details of the registration delimited the rights of the owners.

For eighteenth century patents, the filing of the specification did not provide protection for the complete, or partial, set of words but for the mechanical device that was described by all the words. This required a certain degree of interpretation of the words; what is not clear, though, is the extent to which the specifications of the time could describe more than one invention [237]. Of course, more recently the rules around the detail to be included in the specification have tightened - with the claims of the patent now defining and delimiting the invention [238]. The point here is that in the eighteenth century, the specification, as a technology of ordering, was aimed, in part, at defining the scope of the right - with a significant issue for the technology being the difficulty in describing, for product patents at least, a three dimensional invention in words (and drawings). As with copyright and designs of the time, one of the purposes of the definition of the right was the prevention of the duplication of the creation [239].

In the case of trade marks in the late nineteenth century, however, the protection offered by the Act to the registrants is not simply that which has been entered [240,241]. While it was easier to define the registered mark than it was to describe a patented invention (in many cases, a copy of the mark was pasted into the register), the penumbra of protection offered by the statute extended beyond just the mark itself [242]. As noted above, the test for registration was such that a mark could neither be identical to a registered mark, nor "so nearly resembling" a registered mark "as to be calculated to deceive". A contemporary description illustrates this:

Innumerable cases have come before me as Acting Commissioner where a proposed mark was rejected because it was too near an old mark. A fortnight afterwards there comes another application by the same man to register the same mark with a slight alteration. That is rejected. In another fortnight another attempt is made to register it with another slight variation, and continued attempts are thus made ([243], p. 10).

The trade mark register, therefore, facilitated a set of bureaucratic practices that formalized the broadening protection acknowledged by the courts. The entries themselves no longer marked the limits of the protection. This may be seen as an acknowledgement of the fact that the risks faced by the owners were no longer only simple reproductions. In the trade mark context, these risks were posed by marks that were close enough to cause "confusion" in the minds of purchasers [244].

\subsubsection{Controlling}

The register also allowed knowledge to be controlled. This may be shown in three ways. The first, and this has links to the processes of definition, is the "fixing" of the knowledge. Second is the power of exclusion that is inherent in a register. Finally, there is the shift in the balance of enforcement of the controlled knowledge; and tied to this is the change from the right to reproduce the knowledge to the conceptualisation of the artefacts of knowledge as property [245].

In addition to the register defining the entries, it also "fixed" them in time. Obviously, for patent grants, entry started the clock ticking for the duration of the monopoly [246]. This also applied to the entry of books after the Statute of Anne [247]. The process of registration, notably, allowed a 
comparison of dates. A trade mark could not be entered into the register if it had already been entered by someone else- even if the two individuals came up with the mark independently, the first to register it gained the benefit of the protection. The timing of entry into the register also became important for setting "priority dates" in the assessment of international patent applications - with such dates establishing when an invention should be considered "new" [248].

The register also facilitated both the exclusion of artefacts and the normalisation of that exclusion. Again, obviously, entry with the Stationers' Company meant that the printing of the book had already been authorised by the Crown, so any exclusion occurred prior to entry into the register. Under the Statute of Monopolies, inventions that were not a "manner of new manufacture" did not qualify for a patent (s. 6); however, there was no substantive examination for this until the reforms in the later part of the nineteenth century [249,250]. It was only with the trade mark register that examination, as it is now understood to be, first came to be legislated. Examination also normalised the exclusion of those artefacts that were not intended to be protected by the individual IP regimes. The censorship of books by the Crown was arbitrary [251], and the Statute of Monopolies did not allow the patenting of inventions that were "contrary to the law, nor mischievous to the state... or generally inconvenient" (s. 6), but, again, there was no examination in the early years of the system [252]. Under the trade mark registration regime, however, "scandalous designs" could not be registered [253]; and it was examination that provided the framework for operationalising the exclusion of such marks [254].

Finally, registration facilitated the characterisation, and treatment, of IP as property [255]. This happened in two ways. First, as described above, the register provided clear limits to the protected artefacts. Second, the statutes included provisions for regulating the exchange of interests in the registered artefacts. These provisions made it easier for individuals to buy and sell designs and trademarks - with the capacity to make such contracts being central to the understanding of property qua property [256,257]. Of course, trade marks, in particular, were discussed in terms of property prior to the Trade Marks Registration Act [258]; but the delimitation of the artefacts provided by registration rendered them more fully defined commodities that could be the subject of contracts [259].

Further, the delimitation of IP rights as property, and as the subject of registration, echoed the shift towards the exchange theory of value, evident in the work of the nineteenth-century political economists (a shift away from a Lockean labour theory [260] and the Crown focus of the mercantilists). This, in turn, privileges the role of the individual in the process - in the past, of course, enforcement was a matter for the guilds and the Stationers' Company (in other words, collectives, not individuals, were the core bodies) [261]. Registration facilitated individual action on the parts of rights-holders as they knew what they had (rather than, in the case of trade marks, having to wait for a court to accept their claim of good-will) [262]. In addition, the clear mechanisms for the enforcement of the rights contained in the registration statutes simplified the understanding of the processes for enforcement [263]. The individual capitalists, and their competitors, took centre stage in the regulation of their own competition; because, in part, they just had a piece of paper to fight over [264].

\subsection{Register as Repository of Knowledge}

The second aspect of the "progression" of registers to be considered relates to the changes in nature of the "totality" of the registrations. This is more straightforward than the issue of the delimitation of 
entries as it centres simply on who had access to the information under the different systems. That said, for much of the period under consideration, the nature of the beneficiaries of the knowledge did not change. It is relatively clear, for example, that only the heralds could access the records of the King of Arms. The Stationers' Company also limited access to their Register to those who were in the Company. For both systems, it was only those who needed access to the records who, in fact, could see the entries [265].

The public could, however, access the patent specifications, the register of designs and the register of trademarks - though it was not the person on the Clapham omnibus who had a great interest in the knowledge. It was only in the eighteenth and nineteenth centuries that the competitors of the creators (as opposed to the competitors of the printers) could benefit from knowing what was already protected. This is not to assert that the filing of specifications, in particular, was to enable access; however, as a consequence of the change, others could examine the records in order to see what the subject of the monopoly right was. It is not, however, clear how often competitors in the nineteenth century did search the register in order to find out the state of play of their industry [266].

More importantly, with the advent of the register as a repository of knowledge, the system became more accountable [267]. For a start, a register made it easier to count entries [268]. The register also facilitated examination. The repository of previous grants made it easier for officials to ensure that new applications did not reproduce what had gone before. Further, the "democratisation" of artefacts - the capacity for a greater proportion of the population to own a registered creation-enables the diffusion of what may now be called IP throughout society. In other words, the "objectivity conferred by [registration] establishes a potential domain of "fairness" of that which is above party and peculiar interests" ([269], p. 208). The taking of decisions around what could be protected from those close to the Crown (for example, the Stationers' Company) and giving them to expert, but neutral, civil servants may, therefore, be seen to be indicative of the general shifts in the modes of governance from the post-feudal to the governmental ([270], pp. 17-18).

\subsection{Logical Development or Chance?}

Finally, it may be tempting to view this sequence of changes from a teleological perspective- that is, the regulation of forms of expression developed, or evolved, until the ideal system was arrived at. Such a view may be misguided. Two factors may be seen to counter claims for a teleology. The first is the range of contributing factors to the reforms; and the second is the lack of clear connection, as understood at the time, between the regulatory regimes for the different forms of creation.

Obviously, the discussions above of the contexts of the various systems illustrate that, since the late medieval period, there have been features of British society that have contributed to each form of registration. Without the centralisation of Crown powers, there would have been no capacity for the King of Arms to regulate arms; without the Enlightenment, it is less likely that there would have been such an interest in the detail of the patents applied for; and without the reform movements, and the rise of legal positivism, the nineteenth century registers may not have been created. Further, what has not been mentioned yet is the impact of international changes. While the Trade Mark Registration Act introduced examination to the UK IP system, it was already in existence overseas-including continental Europe and the United States [271]. Other commentators also have highlighted the fact that 
the designs registration system was, in part, based on the French registration system established in 1806 [272,273]; and Duguid states that, by the time the 1875 Trade Mark Act was passed, "the foreign influence on the making of UK trade mark law had become inescapable" ([274], p. 27; [275,276]). The suggestion, therefore, that the UK IP systems were on a pre-destined path from medieval times to the perfection of the nineteenth century seems unlikely.

The other factor counting against a teleological trajectory is the fact that it is not clear that the different categories of IP were understood as having the same rationale - at least not until the late nineteenth century. Patents were about bringing new knowledge into the country (and not about innovation per se) and trade marks were about protecting traders from fraud. Copyright, at least for literary and artistic works, was seen as a distinct category in the nineteenth century - as evidenced by the separate subject matters of the Berne and Paris Conventions. Upton, for example, stated, in 1860, that the "right of property in trade marks does not partake in any degree of the nature and character of a patent or copyright... nor is it safe to reason from any supposed analogies existing between them" ([258], p. 14). That said, as part of the debate around the 1838 Copyright Bill, patents and copyright were seen as "analogous" ([199], p. 70), quoting the then Attorney-General, Sir John Campbell); and Sherman and Bently refer to publications from the 1860s and on for the debate about the greater integration of the different threads of IP ([7], p. 169). An example of this is Lloyd's text on trade marks that justifies their protection, in part, via reference to patents and copyright ([277], pp. 1-2). Of course, the trade marks register was first "established under the superintendence of the Commissioner of Patents" [278]. It wasn't until 1891, however, that there was a textbook that dealt with patents, trademarks, designs, copyright and trade secrets [279]. In other words, there is no guarantee that "reformers" in one area-prior to the mid-nineteenth century at least-would have looked to the systems of another area for guidance and, thereby, limiting the possibility of any teleological momentum.

\section{Conclusions}

In sum, technologies for ordering artefacts reflect their socio-political time and the "complete" registration systems evident in IP today represent a technology rooted in the socio-legal developments of the mid- to late-nineteenth century. The question then may be posed: if these registers reflect the level of technology of a century and a half ago, are they still well-suited to twenty-first century? For example, with the respect to registers being a compilation of all registered artefacts, the system is now not much more than a technological public inspection mechanism in that it allows individuals to have a look at what has already been allowed. The artefacts, and the information about them, are controlled and defined individually with minimal interaction between the entries [280]. This is no advance on the process adopted almost a century and a half ago.

Expressed differently, this article has highlighted that changes as to the organisation of public knowledge took place at an increasing rate from the fourteenth century. Then we hit the end of the nineteenth century and the development of these technologies of ordering knowledge appears to stop. Precise modes of filing may have changed with the advent of computers, but the underlying system is the same. Many understandings of society have changed since 1875-including those around law, economics, politics and knowledge itself [281]—so why not the idea of a register? It is true that 
Burrell has already pointed out that "it is hard to find a truly convincing justification for trademark registration" ([166], p. 97); and Bently raises the question of a possible end to the registration of designs [160]. Neither, however, questions the concept of the register itself. There is not, of course, the capacity here to demonstrate that the register, as a technology, is necessarily out-of-date for the twenty-first century world [282]; the assertion is only that this exploration of its antecedents offers a more contextualised understanding of it that may open up the question of whether registers that persist today are still fit for purpose.

\section{Acknowledgements}

The breadth of this article meant that I have had to take advantage of the generosity of several colleagues. These people included (in no particular order): Sean Bottomley, Matthew Harding, Sam Ricketson, Rain Liivoja, Michael Stuckey, Amanda Scardamaglia and Jeremy Finn. I also need to thank the Melbourne Law School Library Research Service and the Australian Research Council (this research was funded by Linkage Grant LP120100249).

\section{Conflicts of Interest}

The author declares no conflict of interest.

\section{References and Notes}

1. There are similar registers in other jurisdictions as a consequence of, inter alia, the Paris Convention and the Agreement on Trade-Related Aspects of Intellectual Property Rights. Despite the existence of similar regimes in other jurisdictions (colonial Australia, for example, had trade mark registers before the UK did; see Amanda Scardamaglia. "A History of Trade Mark Law in Australia: The Colonial Trade Mark Regime." Ph.D. Thesis, University of Melbourne, 2012), this article focuses on the changes that contributed to the introduction of registration in England.

2. The register was established by the Act to Establish a Register of Trade Marks, 38 \& 39 Vict. c. 91 . It may be noted that a registration system was, before that, proposed in the Trade Marks Bill 1862.

3. The use of the term "technology" here may read a little oddly. Its use is to indicate that it is a form of ordering that is neither natural nor obvious. It is a process that was "invented", or developed over time, in order to fulfil a specific function within a specific system.

4. That first legislative scheme was the Merchandise Marks Act of 1862.

5. These regulatory systems will be discussed in Parts IV and V below.

6. The choice of the awkward phrase "artefact of creation" is, in part, aimed at a subtle, rather than radical, reframing of the issue in that it is intended to include all those creations that are protected by what are now referred to as intellectual property statutes without continuously using the phrase "intellectual property" (as that phrase has developed many connotations that presuppose some of what is in this article).

7. At one level, this research is an expansion of Sherman and Bently's observation that the registration of designs "had antecedents in the patent specification" (Brad Sherman, and Lionel 
Bently. The Making of Modern Intellectual Property Law. Cambridge, UK: Cambridge University Press, 1999, p. 72) by looking at all forms of statutory IP in existence prior to the first "complete" registration technology — that of trade marks.

8. Bowrey asked the question - "But is this history?" in her consideration of the work of others who have looked into the past of copyright: Kathy Bowrey. "Who's Writing Copyright's History?" European Intellectual Property Review 6 (1996): 322-29, p. 326. This article is not a history of IP, it is specifically an engagement with the past to provide a more nuanced perspective of what we have now; it is not an attempt to recreate the full context of what has gone before.

9. The histories of the copyright and patent systems, in particular, are well understood, with these histories accessible through the publications referred to below. As such, only limited discussions of these pasts are needed here.

10. See, for example, Lionel Bently. "The Making of Modern Trade Mark Law: The Construction of the Legal Concept of Trade Mark (1860-1880)." In Trade Marks and Brands: An Interdisciplinary Critique. Edited by Lionel Bently, Jennifer Davis and Jane Ginsburg. Cambridge, UK: Cambridge University Press, 2008.

11. Of course, this section is not about forms of self-expression; however, there is not the room here to discuss a genealogy of the "self" in Western culture.

12. Without meaning to be overly specific, this period, for the purposes of this article is seen to include parts of the fourteenth and fifteenth centuries.

13. It may be noted that the descriptions of the pre-nineteenth century technologies will focus only how they came to be, after a time, and not on how they were instituted (as will be the case for the designs and trade marks registers). The reason for this is two-fold. First, there is much less material available that discusses the introduction of the earlier systems; and, second, the nineteenth century registers were established as a result of specific legislation, whereas those that came before came about, substantially, through changes of informal practices.

14. Schechter states that, "in practically every trade, both in England and on the continent, these marks were compulsory": Frank Schechter. The Historical Foundations of the Law Relating to Trade-Marks. New York: Columbia University Press, 1925, p. 38.

15. For McClure, the marks "facilitated the tracing of defective goods and punishment of the offending craftsman, for the collective good of the guild": Daniel McClure. "Trademarks and Unfair Competition: A Critical History of Legal Thought.” Trademark Reporter 69 (1979): 30556, pp. 310-11.

16. See, for example, Mark McKenna. "The Normative Foundation of Trademark Law." Notre Dame Law Review 82 (2007): 1839-916, p. 1850.

17. As Schechter notes, "merchants coming from a town five miles away might be described" as a "foreigner": [14], p. 41.

18. 7 Hen. IV, c. 7.

19. 19 Hen. VII, c. 6, cl. 3.

20. The master of the craft of pewterers, for example, was authorised to search premises for evidence of the improper use of the pewterer marks: [19], cl. 5.

21. It may be noted that Schechter also discussed the "personal" marks of merchants despite noting that they were "not trade marks at all": [14], p. 20. There is nothing in the role of these 
proprietary marks that warrants their discussion, in this article, in addition to the role of guild marks.

22. It is acknowledged that this is ancient history - even in the late eighteenth century, heraldry was seen as being "obsolete": James Dallaway. Inquiries into the Origins and Progress of the Science of Heraldry in England. London: B \& J White, 1793, p. 1.

23. See, for example, Norma Dawson. "English Trade Mark Law in the Eighteenth Century: Blanchard v Hill Revisited-Another 'Case of Monopolies'?” Legal History 24 (2003): 111-42.

24. Schechter also makes a passing reference to heralds: [14], p. 25.

25. It may be noted that an early historian of heraldry discussed the "marks of merchants" in terms of "conceit"- "this invention was at first practiced for the purpose of marking merchandise, to which armorial ensigns, if possessed, could not have been applied without debasement": Dallaway [22], pp. 119-20.

26. As an aside, there were aspects of the work of heralds that link them to the later traditions of confidential information - the "strict rules of heralds forbade them to give away secret information which their profession might reveal to them": Maurice Keen. The Laws of War in the Late Middle Ages. London: Routledge \& Kegan Paul, 1965, p. 196.

27. There are earlier records of arms — such as the Rolls of Arms by Matthew Paris and the Occasional Rolls — but these were not part of a system of recording of arms. See Richard Marks, and Ann Payne, eds. British Heraldry: From its Origins to c. 1800. London: British Museum, 1978, pp. 12-13.

28. Maurice Keen. Chivalry. New Haven: Yale University Press, 1984.

29. This assessment is not accepted by all commentators, see Peter Ashman. "Heraldry and the Law of Arms in England." Journal of Legal History 9 (1988): 50-86, p. 55.

30. Anthony Wagner. Heralds of England: A History of the Office and College of Arms. London: Her Majesty's Stationery Office, 1967.

31. It is well known that it was in the eleventh century that "Franco-Norman knights bore zoomorphic or geometric devices on their shields", as evidenced by the Bayeux Tapestry: Matthew Strickland. War and Chivalry: The Conduct and Perception of War in England and Normandy, 1066-1217. Cambridge, UK: Cambridge University Press, 1996, p. 137.

32. That said, Ailes notes that the arms depicted in the Bayeux Tapestry "were still not truly heraldic and in the vast majority of cases there is no evidence that they held any special significance or were hereditary": Adrian Ailes. "Heraldry in Twelfth Century England: The Evidence." In England in the Twelfth Century: Proceedings of the 1988 Harlaxton Symposium. Edited by Daniel Williams. Woodbridge: Boydell Press, 1990, p. 2.

33. Expressed differently, arms are the seen as the "adornment of the nobility": [28], p. 143.

34. It may be noted that "noble ladies" were amongst the first people, after the knights, to adopt arms: [30], p. 25.

35. Arms, therefore, may also be tied to later IP regimes on the basis that the Crown used its prerogative to grant rights through the use of letters patent.

36. Anthony Wagner. Heralds and Heraldry in the Middle Ages, 2nd ed. London: Oxford University Press, 1956. 
37. He also notes that the "granting of arms by Kings of Arms, on behalf of the Crown, became in the course of the fifteenth century normal practice": [30], p. 30.

38. It should be noted that rules around the use of "hereditary insignia" began to be established in the late twelfth century; however, these did not include a centralised record of the arms: [28], p. 125.

39. Richard Barber. The Knight and Chivalry. Woodbridge: Boydell Press, 1974.

40. This Court, despite being a civil law court, is still a feature of the English legal system-a dispute was heard under its jurisdiction as recently as the middle of the twentieth century: Manchester Corporation v Manchester Palace of Varieties [1955] P 133. Interestingly, the case was discussed in terms of the defendant using the "arms of the city" in an "attempt to identify the company with the corporation of the city": [1955] P 133, 151 — in other words, it is akin to a passing off case.

41. George Squibb. The High Court of Chivalry. Oxford: Clarendon Press, 1959.

42. This Court may have been created at the time of the Norman invasion, "or at least as early as [the reign] of Edward 1": [41], p. 1.

43. See generally, John Bean. The Decline of English Feudalism 1215-1540. Manchester: Manchester University Press, 1968.

44. It is acknowledged that this is a superficial recitation of school history; however, there is value in linking these simple details with the guild marks, and heraldic arms, systems described above.

45. Milsom notes that the lord's courts may have become "an antiquarian reminiscence" by the end of the thirteenth century: Stroud Milsom. The Legal Framework of the English Feudalism. Cambridge, UK: Cambridge University Press, 1976, p. 35.

46. Lawrence McNamara. Reputation and Defamation. Oxford: Oxford University Press, 2007.

47. For some, it is incorrect to consider that the concept of "the economy" existed prior to the nineteenth century. See, for example, Ryan Walter. "Governmentality Accounts of the Economy: A Liberal Bias?” Economy \& Society 37 (2008): 94-114.

48. In the early fourteenth century, there existed the manorial courts (as opposed to the lord's courts) - the institutions that "controlled the agrarian activities of the manor": John Baker. An Introduction to English Legal History, 3rd ed. London: Butterworths, 1990.

49. Of course, the lords of the manor were not necessarily of sufficient rank to seek arms; however, the nobles that were owed fealty by the manorial lords may have been. For a greater discussion of the courts, including the manorial courts, in the late medieval period, see Frederick Pollock, and Frederic Maitland. The History of English Law before the Time of Edward I. Indianapolis: Liberty Fund, 2010, vol. 1, chap. 3.

50. Fernand Braudel. The Wheels of Commerce. Berkeley: University of California Press, 1992.

51. Plucknett has noted that "a money economy, as opposed to barter in kind, was established in England at a much earlier period, and more extensively than in the in great inland countries of the European continent": Theodore Plucknett. Taswell-Langmeid's English Constitutional History, 11th ed. London: Sweet \& Maxwell, 1960, p. 180.

52. See, for example, Diana Wood. Medieval Economic Thought. Cambridge, UK: Cambridge University Press, 2002, chap. 4.

53. Joseph Strayer. On the Medieval Origins of the Modern State. Princeton: Princeton University Press, 1970. 
54. Michael Clanchy. From Memory to Written Record: England 1066-1307, 2nd ed. Malden: Blackwell, 1993.

55. For a summary of the operation of the patent system in the times of Elizabeth and James, see Chris Dent. "Generally Inconvenient': The 1624 Statute of Monopolies as Political Compromise." Melbourne University Law Review 33 (2009): 415-53 and the works therein cited.

56. Barry Supple. Commercial Crisis and Change in England 1600-1642: A Study in the Instability of a Mercantile Economy. Cambridge, UK: Cambridge University Press, 1959 (emphasis added).

57. Lyman Patterson. Copyright in Historical Perspective. Nashville: Vanderbilt University Press, 1968.

58. Mark Rose. Authors and Owners: The Invention of Copyright. Cambridge, MA: Harvard University Press, 1993, citing Siebert.

59. Ransom, however, states that the "earliest English patents for printing were granted about 1539": Harry Ransom. The First Copyright Statute. Austin: University of Texas Press, 1956, p. 26.

60. It also may be noted that a number of members of the Stationers' Company also held printing patents: [57], p. 80.

61. It is this suggestion that means that the information retained by the Stationer's Company was perceived to be for the benefit of the state rather than just for the benefit of the Company or its members.

62. Ronan Deazley. On the Origin of the Right to Copy. Oxford: Hart Publishing, 2004.

63. See, for example, Benjamin Kaplan. An Unhurried View of Copyright. New York: Columbia University Press, 1967.

64. As an aside, Kaplan notes the "almost obligatory" reference, in his time, to the "communications revolution" that was seen as a challenge to the then copyright regime: [63], p. 1. It is tempting to suggest that the communications revolutions that have taken place since the 1960s have been even more significant - though that would be falling for the sin of taking the experiences of the time out of context.

65. Birrell highlights, for example, that there were grants that covered the "king's books" during, inter alia, the reign of Henry VIII - these included Acts of Parliament, the books relating to the services of the Church of England, Bibles, Law books, Year books, Almanacs and "educational works": Augustine Birrell. Seven Lectures on the Law and Copyright. London: Cassell, 1899, p. 55.

66. As an aside, "all books concerning heraldry, titles of honour and arms" were the subject of a printing licence in 1637: [41], p. 143.

67. There were interactions between the licensors and the printers - "by the mid-seventeenth century ...the state and the Stationers in concert had evolved a complex set of procedures for the establishment and regulation of propriety": Adrian Johns. The Nature of the Book. Chicago: University of Chicago Press, 1998, p. 246.

68. Even in the nineteenth century that books were still required to be lodged with the Stationers' Company: An Act to Amend the Law Relating to International Copyright, 7 \& 8 Vict., c. 12 (1844), s. 6.

69. It was not until the twentieth century that books were required to delivered to the British Museum, instead of the Company: Copyright Act 1911, s. 15-Partridge noting that the change happened "somewhat hastily": Robert Partridge. The History of the Legal Deposit of Books throughout the British Empire. London: Library Association, 1938, p. 114. 
70. Johns, however, considers that the "essentials" of the register "remained much the same" for the life of the Company: [67], p. 216.

71. Birrell sourced the requirement from Arber's recital of a Star Chamber decree of 1637.

72. Of course, such a regulation was not fully effective. For an early study of the "infringement" of the right to publish, see Cyril Judge. Elizabethan Book Pirates. Cambridge MA: Harvard University Press, 1934.

73. It is possible that the Company's efforts were over-enthusiastic. For one commentator, their enforcement included "weekly searches" and they "destroyed illicit books, defaced illegal type, fined, excluded and occasionally imprisoned offending printers on its own authority": David Loades. "The Theory and Practice of Censorship in Sixteenth-Century England." Transactions of the Royal Historical Society 24 (1974): 141-57, p. 155.

74. For a description of the operation of the Court, see Adrian Johns, The Nature of the Book, pp. 196-200.

75. As Rose points out, "claims of infringement and other contentions around copyright were handled not in law courts but by the Company's Court of Assistants": [58], p. 12.

76. Johns is not clear as to when, in the history of the Company, that this taxonomy developed. The only date for a dispute in his discussion of it was 1658 .

77. "Even within the Company itself the register did not enjoy unambiguous recognition. The decision to enter a title was in effect an act of civility by the Stationer to his or her community": [67], p. 220.

78. 8 Anne, c. 19 (1710).

79. Johns describes a couple of specific instances of the failure to make an entry, but does not make any assertions as to how often entries were refused: [67], pp. 217-28.

80. William Letwin. Law and Economic Policy in America. Chicago: University of Chicago Press, 1981.

81. For Pickthorn, "by the end of the fifteenth century", it was clear that "a corporation can be called into existence only by a definite act of the prince": Kenneth Pickthorn. Early Tudor Government-Henry VII. New York: Octagon Books, 1967, p. 138.

82. As another example of the shift in power, under the reigns of the early Tudors, the "commercial gentry came to fill the ranks of the aristocracy as courtiers and statesmen": Ryan Walter. $A$ Critical History of the Economy: On the Birth of the National and International Economies. London: Routledge, 2011, p. 11.

83. Hindle discusses this in terms of the "centripetal tendencies of sixteenth-century government": Steve Hindle. The State and Social Change in Early Modern England. London: Palgrave, 2002, p. 3, citing the work of Elton.

84. It was, of course, in the early modern period that the accounting system known as double-entry book-keeping was developed. See, for example, Luc Lauwers, and Marleen Willekens. "Five Hundred Years of Book-keeping: A Portrait of Luca Pacioli." Tijdschrift voor Economie en Management 39 (1994): 289-304.

85. By the mid-sixteenth century, there were English versions of Pacioli's work and of the work of those who built on his ideas: Jane Gleeson-White. Double-Entry: How the Merchants of Venice Changed the World. Sydney: Allen \& Unwin, 2011, p. 119.

86. Of course, what constituted heresy varied depending on the allegiances of the monarch of the time. 
87. It was, after all, in the sixteenth century that humanism grew in England: John Mackie. The Earlier Tudors 1485-1558. Oxford: Clarendon Press, 1952, p. 235.

88. Of course, there was not a monolithic and stable approach to knowledge in the medieval period-see, for example, Marcia Colish. Medieval Foundations of the Western Intellectual Tradition 400-1400. New Haven: Yale University Press, 1998.

89. See, generally, Roy Porter. The Creation of the Modern World: The Untold Story of the British Enlightenment. New York: W. W. Norton \& Co, 2001.

90. Walter Rüegg. "Themes." In A History of the University in Europe. Edited by Hilde de Ridder-Symoens. Cambridge, UK: Cambridge University Press, 1996, vol. 2.

91. A key exemplar of this is the work of Francis Bacon. Bacon was interested in both practical knowledge and in the organisation, the ordering, of knowledge. See, for example, Stephen Gaukroger. Francis Bacon and the Transformation of Early-Modern Philosophy. Cambridge, UK: Cambridge University Press, 2001. Of course, the work of Bacon had little to do with the origins of the Stationers' Register; however, the technology was developing at the same time that Bacon was working on his ideas. Bacon's influence on the ordering of knowledge in the patent system, however, may have been more significant, as discussed below.

92. The relevance of mercantilism to the early days of the patent system is explored in Thomas Nachbar. "Monopoly, Mercantilism and Intellectual Property." Virginia Law Review 91 (2005): 1313-79.

93. They are also an example of the shift in knowledge production from the "medieval monks" to the secular world: see, for example, Harry Landreth, and David Colander. History of Economic Thought, 2nd ed. Boston: Houghton Mifflin, 1989, p. 28.

94. One of the more significant mercantilists, Thomas Mun, was, for example, a director of the East India Company: Paul Schaafsma. "An Economic Overview of Patents." Journal of the Patent and Trademark Office Society 79 (1997): 241-57, p. 243.

95. For an early history of such companies, see George Cawston, and Augustus Keane. The Early Chartered Companies. London: Edward Arnold, 1896.

96. It has been suggested, for example, that the "great trading companies were the most powerful economic organisations of the time [with] much influence in Parliament": George Clark. "Early Capitalism and Invention." The Economic History Review 6 (1936): 143-56, p. 152.

97. David Keir. The Constitutional History of Modern Britain since 1485, 9th ed. London: Adam \& Charles Black, 1969.

98. One mercantilist argues, for example, that "when trade flourished, the King's revenue is augmented, lands and rents improved, navigation is increased, the poor employed. But if trade decay, all these decline with it": Edward Misselden. Free Trade or the Means to Make Trade Flourish. Amsterdam: De Capo Press, 1622/1970, p. 4.

99. International trade did, of course, occur through the ports such as Bristol and Newcastle. According to Stone, however, the "outports decayed at an alarming rate as London monopolised more and more of the foreign trade": Lawrence Stone. "State Control in Sixteenth-Century England.” Economic History Review 17 (1947): 103-20, p. 107.

100. Further, I have argued elsewhere that the tensions between the outports and London was fuel for the debates around patents in the late sixteenth and early seventeenth centuries: [55], pp. 423-25. 
101. Liah Greenfeld. Nationalism: Five Roads to Modernity. Cambridge, MA: Harvard University Press, 1993.

102. See also, Elizabeth Eisenstein. The Printing Press as an Agent of Change. Cambridge, UK: Cambridge University Press, 1979.

103. The Stationers' Company, of course, is still in existence today. For a history of the Company, see Cyprian Blagden. The Stationers' Company: A History, 1403-1959. Stanford: Stanford University Press, 1960.

104. It may be noted that Jeremy Phillips has highlighted the possible connection between the depositing of books under the Statute of Anne and the enrolment of specifications for patentsreferred to in John Adams, and Gwen Averley. "The Patent Specification: The Role of Liardet v Johnson.” Journal of Legal History 7 (1986): 156-77, p. 161.

105. For example, An Act for the Encouragement of the Arts of Designing, Engraving and Etching Historical and other Prints, 8 Geo II, c. 13 (1735); An Act for the Encouragement of the Arts of Designing and Printing Linens, Cottons, Callicoes and Muslins, 27 Geo. III, c. 38 (1787) and An Act for Encouraging the Art of Making New Models and Casts of Busts, 38 Geo. III, c. 71 (1798). The last statute is of particular interest because it required the creator of a new model or cast to "cause his or her name to be put thereon, with the date of the publication, before the same shall be published and exposed to sale": s. 1. This provision, therefore, has links to the regulation of the provenance of creations and the empowering of the individual with respect to the enforcement of IP rights. The matter of the "individualisation" of regulation of IP is discussed further below.

106. Letters patent, or open letters, were a form of communication of authority that had existed since the medieval period. Tout notes that letters patent were in use from the time of the reign of Henry II: Thomas Tout. Chapters in the Administrative History of Medieval England. Manchester: Manchester University Press, 1967, vol. 1, p. 137.

107. Of course, the use of patents to authorise the sole use of inventions dates, in England, from the sixteenth century: see, Chris Dent. "Patent Policy in Early Modern England: Jobs, Trade and Regulation." Legal History 10 (2006): 71-95; and the works therein cited.

108. One aspect of the records of the patent system that has not been answered satisfactorily is the volumes that were published by Bennet Woodcroft and the Patent Office in the mid-nineteenth century. These volumes of patents and their descriptions started in 1617. They relate only to patents for invention (and not the other grants of the time-such as those for companies, those regulating industries and enforcing statutes). Further, the year that the volumes started was neither a year of a Parliament (and the immediately preceding Parliament was the "Addled Parliament" of 1614) nor one that included a change in monarch-either of which could prompt a bureaucratic reform such as the keeping of records of patents of invention. It has been suggested that Woodcroft based his work on the docket books produced by the Clerk of the Letters Patent-an Office created in Chancery in 1618: Arthur Gomme. Patents of Invention: Origin and Growth of the Patent System in Britain. London: Longmans, Green \& Co., 1946, p. 38. It is, therefore, possible that it was the new Lord Chancellor, who took over in 1618, who was responsible. That Lord Chancellor was Francis Bacon. Given Bacon's interest in knowledge 
and its organisation, it is arguably likely that he started the series, but no definitive answer to this has been established yet.

109. Under the Act for Amending the Law for Granting Patents for Inventions 15 \& 16 Vict. c. 83 (1852).

110. Klaus Boehm. The British Patent System: 1. Administration. Cambridge, UK: Cambridge University Press, 1967.

111. See, for example, Arthur Gomme. "Patent Practice in the Eighteenth Century: The Diary of Samuel Taylor, Threadmaker and Inventor, 1722-1723." Journal of the Patent Office Society 19 (1937): 256-72, pp. 263-65.

112. Christine MacLeod. Inventing the Industrial Revolution: The English Patent System, 1660-1800. Cambridge, UK: Cambridge University Press, 2002.

113. For some sixteenth century examples, see E. Wyndham Hulme. "The History of the Patent System under the Prerogative and at Common Law." Law Quarterly Review 12 (1896): 141-54.

114. D. Seaborne Davies. "The Early History of the Patent Specification III." Law Quarterly Review 50 (1934): 260-74.

115. Davies, as do other commentators, highlights Sturtevant's patent (1611) as an early example of a complex description: [114], pp. 265-68.

116. David Brennan, “The Evolution of English Patent Claims as Property Definers." Intellectual Property Quarterly 4 (2005): 361-99. For those readers not schooled in patent law, the specification remains a formal requirement of the patent system.

117. Sean Bottomley. The British Patent System during the Industrial Revolution, 1700-1852: From Privilege to Property. Cambridge, UK: Cambridge University Press, in press.

118. There is no full report of this decision available. The report of 1 HPC 200 simply reproduces the report of 1 WPC 53; which, in turn, is a brief summary of the decision. There is a report of the subsequent decision in the case, (1780) 1 Y \& CCC 526; 62 ER 1000, but this does not discuss the need for a specification in a patent application. Hulme discusses a newspaper report of the 1778 case and a pamphlet that includes Mansfield's address to the jury in E. Wyndham Hulme. "On the History of Patent Law in the Seventeenth and Eighteenth Centuries." Law Quarterly Review 18 (1902): 280-88.

119. See, further, [104], pp. 161-67.

120. Adam Mossoff. "Rethinking the Development of Patents: An Intellectual History 1550-1800." Hastings Law Journal 52 (2001): 1255-322.

121. For a discussion of the disagreement, see Edward Walterscheid. "The Early Evolution of the United States Patent Law: Antecedents (Part 3)." Journal of the Patent \& Trademark Office Society 77 (1995): 771-802, pp. 779-81.

122. A. V. Newton. “On Patent Agency: Its Origins and Uses. A Retrospective Review." Proceedings of the Chartered Institute of Patent Agents 9 (1891): 125-45.

123. It may be noted that the production of specifications, in the eighteenth century, was carried out without professional assistance. According to Newton, patent agents did not exist as a profession until 1820: [122], p. 129.

124. The French, however, had instituted a system, by the late seventeenth century, that had the Royal Academy of Science "examine all machines for which privileges are solicited from His Majesty; it shall certify whether they are new and useful, and the inventors of those which are approved 
shall leave a model thereof": Frank Prager. "A History of Intellectual Property from 1545 to 1787." Journal of the Patent Office Society 26 (1944): 711-60, p. 752.

125. Oren Bracha. "The Commodification of Patents 1600-1836." Loyola of Los Angeles Law Review 38 (2004): 177-244.

126. One of the key forms of challenge was the writ of scire facias. The writ was used in order to "repeal and cancel the King's letters patent": William Blackstone. Commentaries on the Laws of England. Chicago: University of Chicago Press, 1979/1768, vol. 3, p. 47.

127. The writ of scire facias was available when the letters patent were granted in error or where the patentee has "done an act that amounts to a forfeiture of the grant": [126], pp. 260-61. It, therefore, could be used to challenge a patent that had been granted for an invention that was already protected.

128. For a more complete description of the writ and its manner of use, see Thomas Foster. A Treatise on the Writ of Scire Facias. London: Stevens \& Norton, 1851. It is not clear, however, how often, or successfully, this writ was used to challenge patents for inventions.

129. Edward Walterscheid. "The Early Evolution of the United States Patent Law: Antecedents (Part 3 continued)." Journal of the Patent and Trademark Office Society 77 (1995): 847-57.

130. On a related point, there is some debate in the literature as to the enforceability of patents prior to the reforms of the nineteenth century. Recent research into eighteenth century Chancery bills suggests that patentees did attach "commercial importance" to patents and did endeavour to protect them: Sean Bottomley. "Patent Cases in the Court of Chancery, 1714-1758." Journal of Legal History 35 (2014): 27-43, p. 43.

131. Prager asserts that novelty has always been a key aspect of English law: Frank Prager. "Standards of Patentable Invention from 1474 to 1952." University of Chicago Law Review 20 (1952): 69-95, p. 71. His evidence, however, is limited to cases (such as Mathey's Case) that were not reported and were only referred to in argument for other disputes.

132. Hulme was an early positor of the argument that the specification was in the patentee's interests; see E. Wyndham Hulme. "On the Consideration of the Patent Grant, Past and Present." Law Quarterly Review 13 (1897): 313-18.

133. For a discussion of his arguments, see D. Seaborne Davies. "The Early History of the Patent Specification I." Law Quarterly Review 50 (1934): 86-109, pp. 90-93.

134. Such challenges were not always made by competitors; see, for example, $R v$ Arkwright (1785) 1 CPC 53.

135. It may be noted that it was in 1753 that the "Privy Council relinquished to the law courts jurisdiction over determining the validity of patents for invention; thus putting into effect, albeit 130 years late, section 2 of the Statute of Monopolies": [120], p. 1286. Again, this is an example of a shift away from (relatively) close Crown control to a more independent, but still centralized, system of adjudication.

136. Dutton states that the fee payable at the Enrolment Office was $1 s$ while it was $3 s 6 d$ at either the Petty Bag Office or the Rolls Chapel Office (specifications were enrolled at all three offices): Harry Dutton. The Patent System and Inventive Activity during the Industrial Revolution, 1750-1852. Manchester: Manchester University Press, 1984, p. 198, note 58. Dutton is not clear what dates these figures are from, so it is not obvious how small such a fee was in practice. 
137. Richard Sullivan. "The Revolution of Ideas: Widespread Patenting and Invention during the English Industrial Revolution.” Journal of Economic History 50 (1990): 349-62, p. 361;

138. Also, see generally, Maxine Berg. The Age of Manufactures 1700-1820: Industry, Innovation and Work in Britain, 2nd ed. London: Routledge, 1994.

139. Leon Getz. "History of Patentee's Obligations in Great Britain." Journal of the Patent Office Society 46 (1964): 62-81.

140. Braudel considers that the changes in the economic structure in the seventeenth and eighteenth centuries amounted to a "financial revolution": [50], p. 525. Note, too, that in the early modern period, many patents were owned by members of the court-those who were personally connected to the Crown - this, of course, was the source of some of the complaints about the patent system of the time. The infamous case of Darcy $v$ Allen (1603) 11 Co Rep 84b; 77 ER 1260, for example, involved a groom of Elizabeth's Privy Chamber.

141. Peter Gay. The Enlightenment: An Interpretation. New York: Knopf, 1966, vol. 2.

142. The different conceptualisation of ideas was one of Descartes' key contributions: Bertrand Russell. History of Western Philosophy, 2nd ed. London: George Allen \& Unwin, 1961, p. 548.

143. To be accurate, the patentability of principles was not completely ruled out- "If it were necessary to consider whether or not mere abstract principles are the subject of a patent, I should feel great difficulty in deciding that they are": Hornblower $v$ Boulton (1799) 8 TR 95, 106; 101 ER 1285, 1291, Lawrence J.

144. The first such case in Hayward's compilation of patent decisions is Dollond $v$ ChampneysDollond's "patent is for glasses completely formed, not for mere principles": (1758) 1 CPC 28, 30, Buller J.

145. Of course, working the patent meant that the skill inherent in it was learnt by those charged with the working — or as Dutton put it, "prior to 1734 patents were granted on the condition that a number of tradesmen were taught the mysteries of the art": [136], p. 39.

146. Arkwright v Nightingale (1785) 1 CPC 38.

147. (1788) 1 CPC 35, 37. It is not clear, however, from the various reports of the case whether these are the words of Lord Mansfield or a summary of the judgment.

148. (1795) 2 H Bl 463; 126 ER 651.

149. See, for example, the discussion in Lionel Bently, and Brad Sherman. Intellectual Property Law, 3rd ed. Oxford: Oxford University Press, 2009, pp. 493-94 and the cases therein cited.

150. Both Rose and Patterson highlight the eighteenth century as the period in which the Crown-authorised Stationers' Company lost its primacy and/or authors' rights increased in importance: [58], chap. 5; and [57], chap. 8.

151. Edward. Walterscheid. "The Early Evolution of the United States Patent Law: Antecedents (Part 4)." Journal of the Patent and Trademark Office Society 78 (1996): 77-107.

152. An interesting side-note to this shift is the spreading of risk generally that also began to change in the eighteenth century. There was, for example, a patent granted for a life insurance schemesee D. F. Renn. “John Knox's Plan for Insuring Lives: A Patent for Invention in 1778." Journal of the Institute of Actuaries 101 (1974): 285-89. The article includes a partial recitation of the specification of the patent. 
153. Davies also notes a 1718 petition for a patent that referred to insuring horses, but he does not provide details of the "claim": [133], p. 96.

154. Those being the Paris Convention for the Protection of Industrial Property (1883) and the Berne Convention for the Protection of Literary and Artistic Works (1886). It may be noted that the Paris Convention provides for another link between the IP and heraldic systems - under Article 6 ter of the Convention, countries of the Union are not to allow the armorial bearings of other countries of the Union to be registered as trade marks.

155. These include the Act for Amending the Law for Granting Patents for Inventions 15 \& 16 Vict. c. 83 (1852), the Act to Amend the Law Relating to the Counterfeiting or Fraudulent Use or Appropriation of Trade Marks, and to Secure to Proprietors of Trade Marks in Certain Cases the Benefit of International Protection 25 \& 26 Vict. c. 88 (1862), the Act to Establish a Register of Trade Marks 38 \& 39 Vict. c. 91 (1875) and the Patents, Designs and Trade Marks Act 1883.

156. It may be noted that there are significantly fewer histories of designs legislation than there are for the other forms of statutory IP. It is not clear why this is the case. Four factors may be seen to contribute to this state of affairs - the relative newness of the category; the fewer applications for registration of designs in the modern era that leads to a reduced academic interest; the fact that, as the full title of the 1839 Act suggests, the early years of the regulation of designs were bound up with the copyright doctrine of the time; and finally, as noted by Cornish, IP rights "acquire a real value only when methods of mass production" allow for the exploitation of each form of protection: William Cornish. "Cumulative Protection for Industrial Designs." University of British Columbia Law Review 8 (1973): 219-45, p. 220. For designs, this required the industrial revolution to take place - in particular, the development of mechanised looms for cloth production.

157. 2 Vict., c. 17.

158. The appointment of the Registrar, and the bureaucracy necessary to support the Registrar, is set out in s. 5 of the Act. The Act also sets out penalties, in section 9, where the "Registrar or any person employed under him demand or receive any gratuity or reward, whether in money or otherwise, except the salary or remuneration authorised by the Commissioners of the Treasury"- a provision that is rare in more recent IP legislation; an indicator of the shifts in governance of the bureaucracy itself from the piecemeal approach to a professional civil service.

159. Section 2 of the Act allowed for the transfer of ownership of the designs and for the register to be amended to reflect such a transfer.

160. That is not to say that all applications were accepted unquestioningly-Bently repeats the story that the Registrar had, under the 1839 Designs Registration Act, refused "an obviously unoriginal design which consisted merely of the Queens arms": Lionel Bently. "Requiem for Registration, Reflections in the History of the United Kingdom Registered Designs System." In The Prehistory and Development of Intellectual Property Systems. Edited by Alison Firth. London: Sweet \& Maxwell, 1997, p. 36, note 45-another, albeit tangential, link between IP and the heraldic system.

161. It may be contrasted, therefore, with the administrative regime used for receiving patent specifications - each part of the convoluted process was, while part of the state, a body that was not devoted to the regulation of patents.

162. 2 Vict., c. 13. 
163. 1839 Designs Act.

164. 5 \& 6 Vict., c. 100 .

165. C. Weston. "The Legal Protection of Industrial Designs." University of Western Australia Law Review 10 (1971-1972): 65-83, citing the 1836 Report from the Select Committee on Arts and Principles of Design.

166. Burrell has already pointed out the important distinction between a "bare registration" or "deposit" system and one that includes formal examination: Robert Burrell. "Trade Mark Bureaucracies." In Trademark Law and Theory: A Handbook of Contemporary Research. Edited by Graeme Dinwoodie and Mark Janis. Cheltenham: Edward Elgar Publishing Limited, 2008, p. 96 , note 3 .

167. With respect to the Act's success in the market- "judging by the number of trade mark registrations which followed the 1875 Act, it does appear that businessmen responded enthusiastically": David Higgins. "The Making of Modern Trade Mark Law: The UK, 1860-1914. A Business History Perspective." In Trade Marks and Brands: An Interdisciplinary Critique. Edited by Lionel Bently, Jennifer Davis and Jane Ginsburg. Cambridge, UK: Cambridge University Press, 2008, p. 49.

168. No details, however, of the registration process - such what needed to be included in the application-were included in the Act itself.

169. The Act does not state that the register must be open for public inspection, only that the "Lord Chancellor may from time to time...make, and, when made, alter, annul, or vary, such general rules as to...the persons entitled to inspect the register..." The Rules released by the Trade Mark Registry Office, however, stipulated that "any person may, on paying the prescribed fee, inspect the register of trademarks; and any person may, on paying the prescribed fee, obtain an office copy of any entry in the register": Rule 40, reproduced in Frank Adams. A Treatise on the Law of Trade Marks. London: Butterworths, 1876, p. 187.

170. Of historical interest is that there is a section, one that incorporates seven sub-sections, that regulates the marks of the Cutlers Company and those of the Sheffield Company: Trade Marks Registration Act, s. 9.

171. It may be noted, though, that one of the key benefits of the Trade Marks Registration Act was the fact that protection could be gained for marks without requiring that they had been used before.

172. Lionel Bently. "From Communication to Thing: Historical aspects of the Conceptualisation of Trade Marks as Property." In Trademark Law and Theory: A Handbook of Contemporary Research. Edited by Graeme Dinwoodie and Mark Janis. Cheltenham: Edward Elgar Publishing Limited, 2008.

173. See, for example, [10], pp. 7-16.

174. As an aside, there was a pre-registration trade mark decision that allowed two distinct plaintiffs to sue defendants for the infringement of the same mark: Dent $v$ Turpin (1861) 2 J \& H 139; 70 ER 1003. In that case, the two plaintiffs operated different businesses but both used the same trade mark - relating to their shared surname - that had been first used by a common ancestor.

175. It appears that the purpose of the classification was either, or both, obvious or uncontroversial, as treatises of the time had no discussion of it. See, for example, [169]; and Charles Drewry. The Law of Trade Marks. London: Knight \& Co., 1878. 
176. Bryce, in his supplement to Ludlow and Jenkyns' Treatise, highlights the impact of the requirement of classification for old marks (such as the need for them to be registered with respect to particular descriptions of goods rather than just with respect to a particular class of goods), but does not discuss why classification was introduced: James Bryce. "The Trade Marks Registration Acts 1875 \& 1876." being a supplement to A Treatise on the Law of Trade Marks and Trade Names. Edited by Henry Ludlow and Henry Jenkyns. London: William Maxwell \& Son, 1877.

177. It was also raised in Singer Machine Manufacturing $v$ Wilson (1876) LR 2 Ch 434. This decision was handed down after the Trade Mark Registration Act came into effect but was not decided on the basis of the Act's provisions. It is possible, however, that this key aspect of the Act may have influenced the minds of the judges.

178. (1866) LR 1 Eq 518, Page-Wood VC.

179. (1863) 4 De G \& J 150, Westbury LC.

180. (1863) 4 De G \& J 137, Westbury LC.

181. In the case of Hall $v$ Barrows, however, the dispute was about the limits of the transfer of a trade mark after the death of a person in a partnership (with the mark having been attached to the partnership).

182. It should be noted that the classification scheme adopted was one based on the scheme used in the Great Exhibition of 1851: [1], p. 70.

183. Cornish, for example, refers to Hindmarch whose efforts in the 1860 s were fuelled by a "fear of undue monopoly": William Cornish. "Industrial Property: Trade Marks and Unfair Competition." In The Oxford History of the Laws of England: Volume XIII: 1820-1914 Fields of Development. Edited by William Cornish, J. Stuart Anderson, Ray Cocks, Michael Lobban, Patrick Polden and Keith Smith. Oxford: Oxford University Press, 2010, p. 1000.

184. See, for example, [7], pp. 174-76.

185. Llewellyn Woodward. The Age of Reform 1815-1870, 2nd ed. Oxford: Clarendon Press, 1962.

186. For more thorough readings in the area, see Frederick Rosen. Classical Utilitarianism from Hume to Mill. London: Routledge, 2003.

187. Geoffrey Scarre. Utilitarianism. London: Routledge, 1996.

188. Gerald Postema. "Bentham's Utilitarianism.” In Blackwell Guide to Mill's Utilitarianism. Edited by Henry West. Malden: Blackwell, 2006.

189. John Grote. An Examination of the Utilitarian Philosophy. Bristol: Thoemmes, 1990.

190. Philip Schofield. "Jeremy Bentham and Nineteenth English Jurisprudence." Journal of Legal History 12 (1991): 58-88. It may be noted that this is by no means an exhaustive listing, but simply a number of the pieces that I have found useful in my research.

191. One commentator has noted that "unlike some of his more recent disciples...Bentham was fully aware of the complexities of assessing and estimating pleasures": [186], p. 179.

192. Bentham, famously, was not keen on the common law; "Bentham criticised virtually every facet of common law jurisprudence for its general obscurity, inaccessibility and illogicality": Margaret Davies. Asking the Law Question, 2nd ed. Sydney: Lawbook Co, 2002, p. 60. As a result, he thought that change should be legislated. 
193. It has been suggested that it may be noted that the nineteenth century "law reformers, whether in or out of Parliament...were all at bottom individualists": Albert Venn Dicey. Lectures on the Relation between Law and Public Opinion in England during the Nineteenth Century. Indianapolis: Liberty Fund, 2008, pp. 120-21.

194. In sum, the reform of the law, particularly in this area, reflected utilitarian understandings. Mill, for example, speaks of individuals as "free agents" and discusses the enforceability of contracts in terms of, amongst other things, fraud - a key basis of trade mark law: John Stuart Mill. Principles of Political Economy. Amherst: Prometheus Books, 2004, pp. 728-30.

195. It may also be noted that details such as the articles of association of companies began to be registered under the Companies Act 1862; further, owners of hackney carriages (and other vehicles) for hire were required to be licensed, and the vehicles to carry licence plates, under the Act to Amend the Laws relating to Hackney Carriage, and to Waggons, Carts, and Drays, used in the Metropolis; and to place the Collection of the Duties on Hackney Carriages and on Hawkers and Pedlars un England under the Commissioner of Stamps, 1 \& 2 Will. IV, c. 22, s. 7 (1831).

196. More fully, An Act for enabling Town Councils to establish Public Libraries and Museums, 13 \& 14 Vict., c. 65.

197. The public libraries financed under this Act may be contrasted with the "commercial circulating libraries" that existed in the eighteenth century: Michael Harris. History of Libraries in the Western World, 4th ed. Lanham: Scarecrow Press, 1999, p. 152.

198. See, generally, Alistair Black. A New History of the English Public Library. London: Leicester University Press, 1996, chap. 3. It may be noted that Black emphasises the "empirical" aspect of the utilitarian mission (for example, pp. 45-48) which ties in with the positivist approach to knowledge.

199. Catherine Seville. "Talfourd and his Contemporaries: The Making of the 1842 Copyright Act." In The Prehistory and Development of Intellectual Property Systems. Edited by Alison Firth. London: Sweet \& Maxwell, 1997.

200. Matthew Battles. Library - An Unquiet History. New York: W. W. Norton \& Co., 2003.

201. Stuart Murray. The Library: An Illustrated History. New York: Skyhorse Publishing, 2009.

202. The Moys classification system, used in a number of law libraries, was a mid-twentieth century development. For a description of the challenges of cataloguing in law libraries, see Marion Birch. "Cataloguing and Classification." In Manual of Law Librarianship: The Use and Organisation of Legal Literature, 2nd ed. Edited by Elizabeth Moys. Boston: G. K. Hall, 1986.

203. It may be noted that more simple processes of ordering the trade mark register had been proposed. An "alphabetical listing”, presumably by owner's name, had been suggested during the hearings of the Select Committee investigating the two Bills of the early 1860s: Select Committee on the Trade Marks Bill and Merchandize Marks Bill, Report, 1862, p. 5.

204. As a result of the Act for Keeping Safely the Public Records, 1\& 2 Vict., c. 94.

205. John Cantwell. "The 1838 Public Record Act and its Aftermath: A New Perspective." Journal of the Society of Archivists 7 (1984): 277-86.

206. John Cantwell. "The Public Record Office: The Legal and Departmental Records." Journal of Legal History 2 (1981): 227-37, quoting Sir Francis Palgrave. 
207. On a related, but even more tangential, note - there was a debate in the middle of the nineteenth century about the best way of assessing an applicant's suitability for the public service, with two of the options being a "mere pass examination" or one that had a more competitive element. There was even discussion about the impact, in terms of the morality of successful applicants, of each method. See, for example, Edwin Chadwick. "On the Progress of the Principle of Competitive Examination for Admission into the Public Service." Journal of the Statistical Society of London 22 (1859): 44-75. This debate highlights the privileging of knowledge in public administration and the ordering of those with differing levels of knowledge.

208. Reference may also be made to the broader philosophic movement of positivism. A key feature of that movement is its emphasis on "empirical evidence as the source of knowledge": David Oldroyd. The Arch of Knowledge. Sydney: New South Wales University Press, 1986, p. 169.

209. Further, postivism may be understood to be a "collection of rules and evaluative criteria referring to human knowledge": Leszek Kolakowski. Positivist Philosophy: From Hume to the Vienna Circle. Harmondsworth: Penguin, 1972, p. 11.

210. There are links between positivism to utilitarianism (Kowalski, for example, ties the work of John Stuart Mill to positivism: [209], p. 96), including the "moral and political aspect" to positivism (John Burrow. Evolution and Society: A Study in Victorian Social Theory. Cambridge, UK: Cambridge University Press, 1966, p. 102) that is evident also in utilitarianism.

211. See, generally, Richard Nobles, and David Schiff. "Debating with Natural Law: The Emergence of Legal Positivism." In Introduction to Jurisprudence and Legal Theory. Edited by James Penner, David Schiff and Richard Nobles. Oxford: Oxford University Press, 2005.

212. See, for example, [190] and Amanda Perreau-Saussine. "Bentham and the Boot-Strappers of Jurisprudence: The Moral Commitments of a Rationalist Legal Positivist." Cambridge Law Journal 63 (2004): 346-83. Perreau-Saussine goes so far as to label Bentham a "rationalist legal positivist": p. 351.

213. Schofield, in another publication, highlights Bentham's techniques of ordering of abstract concepts: Philip Schofield. "John Stuart Mill on John Austin (and Jeremy Bentham)." In The Legacy of John Austin's Jurisprudence. Edited by Michael Freeman and Patricia Mindus. London: Springer, 2013, p. 248.

214. See, for example, the diagram that precedes his first lecture on jurisprudence: John Austin. Lectures on Jurisprudence. Bristol: Thoemmes, 2002, vol. 1, p. 79.

215. Roger Cotterrell. The Politics of Jurisprudence. London: Butterworths, 1989.

216. Catharine Macmillan. "Stephen Martin Leake: A Victorian's View of the Common Law." Journal of Legal History 32 (2011): 3-29.

217. See, for example, [7], pp. 174-76. It may be noted the Sherman and Bently in this discussion do not discuss, separately, the relevance of the language of political economy and utilitarianism to the changes in the IP system.

218. For a discussion, that pre-dates that of Locke, of the link between labour and property see [52], pp. 24-25 citing the work of John of Paris and Fortescue.

219. Wendy Gordon. "A Property Right in Self-Expression: Equality and Individualism in the Natural Law of Intellectual Property.” Yale Law Journal 102 (1993): 1533-609. 
220. Steven Horowitz. "Rethinking Lockean Copyright and Fair Use.” Deakin Law Review 10 (2005): 209-32.

221. That is not to say that their understanding of labour was simplistic. Jevons, one of the later nineteenth-century writers in the realm of political economy had a complex understanding of the input. See the discussion in Harro Maas. "Jevons, Mill and the Private Laboratory of the Mind." The Manchester School 73 (2005): 620-49, pp. 636-40.

222. Michel Foucault. The Order of Things. London: Routledge, 2002.

223. See, generally, Joseph Schumpeter. History of Economic Analysis. Edited by Mark Perlman. New York: Oxford University Press, 1994, chap. 6.

224. It has been argued that the legal system had begun to understand the law in terms of an exchange theory of value from the middle of the eighteenth century: James Bergeron. "From Property to Contract: Political Economy and the Transformation of Value in English Common Law." Social \& Legal Studies 2 (1993): 5-23, pp. 12-17.

225. Quoted in Jill Gordon. "John Stuart Mill and the "Marketplace of Ideas." Social Theory and Practice 23 (1997): 235-49.

226. As an aside, Mossoff has argued that "Locke's labour theory of value provided a moral framework with which to protect the inventor's labours": [120], p. 1289.

227. For example, piracy of designs was defined to include the "fraudulent imitation" of a design: Act to Consolidate and Amend the Laws relating to the Copyright of Designs for Ornamenting Articles of Manufacture, 5 \& 6 Vict., c. 100 (1842), s. 7; and trade marks that were "calculated to deceive" were not allowed to be registered under the Trade Marks Registration Act: s. 6. It may be noted, however, that piracy under the 1839 Designs Registration Act was limited to the use of the registered design "or any original part thereof": s. 3.

228. George Feaver. From Status to Contract: A Biography of Sir Henry Maine. London: Longmans, 1969.

229. Expressed differently, K. B. Smellie is quoted as saying that "Maine accepted the Ricardian economic man as the goal of progress": [210], p. 156.

230. More specifically, Maine's work Ancient Law considered "contract" to reflect the end-point of progress in societal relations. Notably "he believed that a society based on contract was a society in which, of necessity, individuals had come to adopt high moral standards, and these standards, he believed, enabled them to trust each other in the course of commercial and other dealings": Raymond Cocks. Sir Henry Maine: A Study in Victorian Jurisprudence. Cambridge, UK: Cambridge University Press, 1988, p. 61.

231. Further, Vinogradoff has noted that Maine drew parallels between the work of Bentham and Austin and that of the political economists: Paul Vinogradoff. The Teaching of Sir Henry Maine: An Inaugural Lecture. London: Henry Frowde, 1904, p. 6.

232. Sherman and Bently discusses this in terms of the "closure of intangible property": [7], p. 180.

233. The language of arms, including the defined parts of the arms (such as escutcheon, supporters, helm), the specific and limited colours (azure, gules, sable etc.) and patterns (barry, paly, fleur-delis etc.) used, means that a complex image can be described effectively in a discursive form.

234. Arguably, guild marks were not commercial in the way that later IP rights were. No individual owned a guild mark and there was not competition between those that used the mark (at least, not on the basis that the mark showed one person's goods were better than another's). 
235. There is, unsurprisingly, little evidence of the extent of piracy in the early modern period. Mark Rose notes that "genuinely unauthorised publication was rare" at the time: [58], p. 21. He, as well as other commentators, such as Johns [67], discuss piracy only in terms of complete duplication of books, rather than in terms of partial copying.

236. It may be noted, though, that infringement, under the 1842 Designs Act involved the "fraudulent imitation" of a registered design: s. 7.

237. For MacLeod, eighteenth century specifications "could be as informative or as evasive as the patentee saw fit": [112], p. 49.

238. Patents Act 1977 s. 14. For a history of the use of claims in patents, see [116].

239. It may also be noted that the patent system, unlike the other three IP regimes, had engaged with the issue of the regulation of "follow-on" innovations. In the early modern period, patents could not be valid if they protected an improvement of a pre-existing technology (see, for example, Bircot's Case (1572) and Mathey's Case (1571) — no report of either decision remains). It was in the late eighteenth century that such an approach was over-turned. In his address to the jury in Morris v Bramsom, Mansfield is reported to have said, "if the objection to the patent on the grounds of the invention being only an addition to an old machine were to prevail, that objection would go to repeal almost every patent that was ever granted": (1776) 1 CPC 30, 34. See, further, [112], p. 13.

240. Trade mark registrations, therefore, may be contrasted with the land registers that were developed in the nineteenth century - such as under the Torrens system used in colonial Australia. Pottage has described the processes by which the cartographic developments of that century impacted on the precision of defining land (for the purposes of tracking and controlling it): Alain Pottage. "The Measure of Land.” Modern Law Review 57 (1994): 361-84.

241. For a more complete reading of the changes to land reforms, see J. Stuart Anderson. Lawyers and the Making of English Land Law 1832-1940. Oxford: Clarendon Press, 1992.

242. It may be noted that in other areas of IP, the courts had begun, by the middle of the nineteenth century, to extend protection beyond the specifics of the grant. For example, Pollock CB stated, in the context of the possible infringement of a patent, that "it would be a question for the jury whether that used was not substantially the same thing" as the invention described in the patent": Sellers $v$ Dickinson (1850) 5 Exch 312, 325; 155 ER 134, 142. Therefore, while the additional protection offered by the Trade Marks Registration Act 1875 was new to statute law, it was not a totally new concept to IP law generally (it should be pointed out, too, that it was only in the mid-nineteenth century that the penumbra was seen to extend around any IP right).

243. In re Worthington's Application (1880) 14 Ch D 8, Jessel MR.

244. The first judicial mentions of the possibility of two marks being confused occurred soon after the introduction of the registration system. In 1886, the abstract point was made that "small marks are more likely to be confused than large marks": In re Lyndon's Trade Mark (1886) 3 RPC 102, 107, Fry LJ. In another judgment in that year it was held that "no instance has been shown where it is possible that anybody could be, I do not say deceived, but there could be any confusion or any misleading" arising from the use of the mark: In re Leaf's Trade Mark (1886) 3 RPC 289, 291, Bacon VC. The first use of the term "confusion" in a decision of the House of Lords in the area of trade mark is in Eno v Dunn (1890) 15 App Cas 251, 263, Lord Macnaghten. 
245. As an aside, it may be note that registration is not the only way to achieve these ends. The doctrine of confidential information also developed significantly in the nineteenth century. It also "fixed" knowledge and allowed for it to be controlled (and subject to licence agreements), though not technically "owned". See generally Megan Richardson, Michael Bryan, Martin Vranken, and Katy Barnett. Breach of Confidence: Social Origins and Modern Developments. Cheltenham: Edward Elgar, 2012.

246. Under the Statute of Monopolies, a patent for invention could last for no more than 14 years: s. 6 . Under the early nineteenth century reforms, patents could be extended past that time: An Act to Amend the Law Touching Letters Patent for Invention 5 \& 6 Will. IV, c. 83 (1835) s. 4,

247. The Act provides for a monopoly of 21 years for printing books that were already in existence and a monopoly of 14 years for those "that shall hereafter be composed": s. 2.

248. The Paris Convention has already been referred to; there were, in addition, earlier bilateral agreements that regulated the granting of patents for inventions from another country. Ladas lists 69 such agreements. Great Britain entered into treaties or conventions, relating to IP, with Russia (1859, 1871), Columbia (1866), Austria-Hungary (1876), the United States (1877), Denmark (1879), Ecuador (1880), Portugal (1880), Switzerland (1880), France (1882) and Montenegro (1882). See generally, Stephen Ladas. Patents, Trademarks and Related Rights: National and International Protection. Cambridge: Harvard University Press, 1975, vol. 1, part 1. Of course, registration in an applicant's home country also acted as proof that the artefact did exist prior to the applicant seeking reciprocal acknowledgment of the artefact in another country.

249. It may be noted that a register of specifications, open for the inspection of the public, was created under An Act for Amending the Law for Granting Patents for Inventions, 15 \& 16 Vict., c. 83, (1852), s. 29. Under the Patents, Designs and Trade Marks Act 1883, a patent application could be opposed, within two months of the acceptance of the complete specification, on grounds including the ground that the invention had already been patented in the UK: s. 11. But it was not until 1905, after the Patents Act 1902, that there was examination into the novelty of the patent applications: [108], p. 41.

250. It also may be noted that the nineteenth century patent reforms were introduced as a result of a widespread dissatisfaction with the system that existed in the first half of that century. The level of the dissatisfaction was so high that there was a concerted push to get rid of the system entirely. See, for example, the discussion in Fritz Machlup, and Edith Penrose. "The Patent Controversy in the Nineteenth Century." Journal of Economic History 10 (1950): 1-29.

251. Censorship was arbitrary in the sense that there were no rules as to what should be banned, a significant discretion on the part of the Crown with respect to the banning and no clear process for challenging any ban.

252. It may also be pointed out that the examination of a patent application is not the same conceptually as the examination of a trade mark application. The verbal and diagrammatic representations of an invention, for example, require a greater degree of interpretation than does the assessment of a new trade mark - in addition to the greater number of legal hurdles that a patent application, now, has to clear (novelty, inventive step, subject matter and sufficiency of disclosure versus subject matter and distinctiveness). 
253. Trade Marks Registration Act s. 6. It is not clear, however, how many applications were not registered on the basis of the marks being scandalous; it is, nonetheless, significant that the legislature created this category of marks that could be denied registration.

254. .It may also be noted that other pre-1875 IP statutes did not seek to exclude artefacts for moral reasons. See, for example, An Act for Encouraging the Art of Making New Models and Casts of Busts, 38 Geo. III, c. 71 (1798) and the 1839 and 1842 Design Registration Acts.

255. The characterisation of all types of artefacts of creation as property did not sit well with all in the nineteenth century. One commentator suggested that "literary compositions" were "far more of the nature of property" than inventions or designs as the latter two categories were much more prone to simultaneous development - "I believe...that nearly all the most important discoveries in mechanical and cognate processes have been made simultaneously": James E. Thorold Rogers. "On the Rationale and Working of the Patent Laws." Journal of the Statistical Society of London 26 (1863): 121-42, p. 135.

256. For Mossoff, "acquisition, use and disposal" are "necessary" for a complete description of property: Adam Mossoff. "What is Property? Putting the Pieces Back Together." Arizona Law Review 45 (2003): 371-443, p. 376.

257. For an alternative view of the intersection of property and contract, see further James Penner. The Idea of Property in Law. Oxford: Clarendon Press, 1997, chap. 7.

258. It should be noted, though, that most of the references in the case law came about the time, or after, an 1862 Bill referred to trade marks as property: [172], p. 16. Upton, admittedly in a treatise published in the US, discusses, in 1860, the English case law in terms of trade marks as property: Francis Upton. A Treatise on the Law of Trade Marks. Albany: Weare C Little, 1860, Ch. 1. The subsequent UK cases that referred to marks as property include Cartier $v$ Carlisle (1862) 31 Beav 292; 54 ER 1151; Edelsten v Edelsten (1863) 1 De G \& J 185; 46 ER 72; Leather Cloth Co. v American Leather Cloth Co (1863) 4 De G \& J 137; 46 ER 868; and Hall v Barrows (1863) 4 De G \& J 150; 46 ER 873. Further, Schechter noted that there was "extreme reluctance" on the part of the "witness before the Parliamentary Committee of 1862 to interpret trade mark rights in terms of property": [14], p. 141; conversely, one witness before the Committee considered a cutlers' mark to be "property" that could be "sold from one man to another": [203], p. 6. As an aside, to split hairs, the judge in the famous case of Millington v Fox did not refer to the mark in question as property but did consider whether the "plaintiffs had a title to the marks": (1838) 3 My \& Cr 338, 352; 40 ER 956, 961. The headnote to that decision, however, did refer to marks as property.

259. This represents another distinction between the registration of artefacts of creation and that of real property. The latter is as much about the control of obligations relating to a piece of land as it is about facilitating its exchange (see, generally, Pamela O'Connor. "Registration of Title in England and Australia: A Theoretical and Comparative Analysis." In Modern Studies in Property Law, Volume 2. Edited by Elizabeth Cooke. Oxford: Hart, 2003). Given the relatively straightforward nature of interests in artefacts of creation, their registration is much more about the regulation of their exchange.

260. It is arguable, too, that the goodwill inherent in pre-registration trade mark disputes was a reflection of the labour, or effort, the mark's owner put into the business. 
261. It is true that the King of Arms was responsible for monitoring the use of arms; however, it may be better to see the King of Arms as an office of the Crown, rather than an individual, and the subject matter of the enforcement was a matter of political standing and not an economic right.

262. Bently has noted that the "absolute monopoly" offered by registration is a significant advantage to registrants as it simplifies what has to be proven in order to win judgment: [160], p. 41.

263. The political economists of the time were early adopters of the "belief that the state never did things well": [185], p. 446. For a detailed discussion of Mill's understanding of the role of the government, see [194], Book V. In terms of the IP regimes, Dutton has noted that "for the classical economists, patents were not a burning issue; their observations were usually expressed only as part of larger arguments concerning monopolies, the role of government and the consequences of the division of labour": [136], p. 20.

264. It is possible, and more contentious, that the infringement of a statutory right is less "immoral" than the "fraud" associated with the forms of infringement that existed earlier. In the trade mark context, after the 1875 Act there was no need to prove that the owner or "possessed" any goodwill - any connection with customers that could be "betrayed" by the deceptive actions of the defendant. It is clear that the language of litigation shifted from "fraud" and "deception" to the less pejorative "confusion"; the contribution of the registration process itself to this change is less clear. There is little discussion in the literature about the shift in the discourse from "fraud" to "confusion"; but note - the "prevalence of the user of confusion rather than deception may be caused by a certain squeamishness on the party of claimants and judges to brand defendants add responsible for deception when there is no deliberate attempt to deceive": David Kitchin, David Llewellyn, James Mellor, Richard Meade, Thomas Moody-Stuart, and David Keeling. Kerly's Law of Trade Marks and Trade Names, 14th ed. London: Sweet \& Maxwell, 2005, p. 445, note 81.

265. The relatively small number of those entitled to bear arms meant that, in most cases, an "applicant" did not need to know what was already out there before requesting arms (though duplication did happen). Further, in the early modern period, it was, to a large extent, only the stationers who had the capacity to print books and, therefore, only they needed to know who was entitled to print which books.

266. No records appear to have been kept about the number of people who paid to inspect the registers. Further, and somewhat tangentially, it has been suggested that, in the nineteenth century, "little interest was taken by British employers...in the collation of commercial information for research purposes": [198], p. 131. In other words, UK firms were not interested in the generation of knowledge for knowledge's sake - this may be indicative of the general approach, on the part of business people, to abstract knowledge of the time.

267. In other contexts, registration allowed for the apportionment of liability- the registration of ships, for example, allowed the ownership of a ship to be traced after a collision involving a registered ship. Further, the Merchant Shipping Act 1854 provided specific instructions as to how ships were to measured (their tonnage and their beam: ss. 23, 24); who could act as registrar (s. 30); regulations as to the custody of the certificate of registration (s. 50); transfer of registration (s. 55); inspection of register books (s. 92) the liabilities of owners (s. 100); and rules about the "national character" of ships (ss. 102-106). Note, however, that the nineteenth century statute 
was not the first to regulate shipping. See, for example, An Act for the Increase of Shipping and Encouragement of Navigation of this Nation (1651). This Act did not include a registration system.

268. It was, for example, after the 1875 Trade Mark Registration Act that the Patent Office produced reports that detailed the number of patent applications made each year. See, generally, Paul Duguid, Teresa da Silva Lopes, and John Mercer. "Reading Registrations: An Overview of 100 Years of Trademark Registrations in France, the United Kingdom, and the United States." In Trademarks, Brands, and Competiveness. Edited by Teresa da Silva Lopes and Paul Duguid. New York: Routledge, 2010. In contrast, no such reports were produced after the requirement for patent specifications was introduced.

269. Nikolas Rose. Powers of Freedom: Reframing Political Thought. Cambridge, UK: Cambridge University Press, 1999.

270. Peter Miller, and Nikolas Rose. Governing the Present: Administering Economic, Personal and Social Life. Cambridge, UK: Polity Press, 2008.

271. The US, for example, had introduced examination into its patent law in 1836: Patents Act $1836 \mathrm{~s}$. 7. Though, as Drahos notes, "in the nineteenth century no country had a patent office doing substantive examination across the range of criteria that modern offices examine against": Peter Drahos. The Global Governance of Knowledge: Patent Offices and their Clients. Cambridge, UK: Cambridge University Press, 2010, pp. 33-34.

272. See, for example,[156], p. 222.

273. According to Lahore, there is no doubt that the French law was uppermost in the minds of many of the members of the House of Commons' during the parliamentary debates on the designs legislation: James Lahore. "Art and Function in the Law of Copyright and Designs." Adelaide Law Review 4 (1971-1972): 182-209, p. 186.

274. Paul Duguid. "French Connections: The International Propagation of Trademarks in the Nineteenth Century." Enterprise \& Society 10 (2009): 3-37. Duguid made this statement in the context of the significant discussion of European registration systems by the 1862 Select Committee. Again, this discussion only indicates international influence in the later stages of the implementation of registration systems.

275. As an aside, it may be noted that there was very little discussion of foreign registers in the Report of Commission investigating the registration of land titles: Report of the Commissioners Appointed to Consider the Subject of the Registration of Title with Reference to the Sale and Transfer of Land, 1857. This is despite the fact that a German system has been (erroneously according to Taylor) described as a key factor in the Torrens registration system adopted in colonial Australia in the 1850s: see Greg Taylor. "Is the Torrens System German?" Journal of Legal History 29 (2008): 253-85.

276. Taylor also notes that the Torrens himself acknowledged the Merchant Shipping Act 1854 as a source for his land registration system: Greg Taylor. "The Torrens System-Definitely Not German.” Adelaide Law Review 30 (2009): 195-212, p. 199.

277. Edward Lloyd. The Law of Trade Marks, 2nd ed. London: Yates and Alexander, 1865.

278. Trade Marks Registration Act 1875, s. 1.

279. With that book being Wyndham Bewes. Copyright, Patents, Designs, Trade Marks etc-A Manual of Practical Law. London: A \& C Black, 1891. 
280. It is not argued that there is not more information recorded on the register than there was in the nineteenth century (such as the recording of security interests in marks); however, the underlying technology remains the same. Of course, too, registers are now global (such as that controlled by the World Intellectual Property Organisation for the recording of trade mark applications under the Madrid Protocol); however, that still does not indicate a higher level of technological or epistemological complexity.

281. As concrete examples, libraries today are significantly different to those created under the Public Libraries Act 1850 and the nineteenth century civil servants would not recognise the operation of the government today.

282. It may be that a database, rather than a register, may be more appropriate now-with the difference between the two based on the interaction (or relationships), and analysis, of the different fields in the record rather than just the simple applications and queries that dominate the system now. As a (random) example of work in the area of information management today see Birger Hjorland, and Karsten Pedersen. "A Substantive Theory of Classification for Information Retrieval." Journal of Documentation 61 (2005): 582-97. The ideas behind such research are well beyond the understandings of knowledge in the nineteenth century that contributed to the establishment of registers.

(C) 2014 by the author; licensee MDPI, Basel, Switzerland. This article is an open access article distributed under the terms and conditions of the Creative Commons Attribution license (http://creativecommons.org/licenses/by/3.0/). 